\title{
A Sprinkler Fire Suppression Algorithm for the GSA Engineering Fire Assessment System
}

Daniel Madrzykowski

Robert L. Vettori

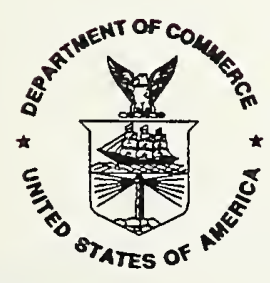

$-Q C$

100 Jepartment of Commerce

.456

4833 nal Institute of Standards and Technology 1992

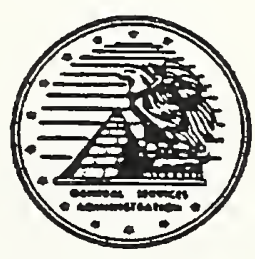

Prepared for:

General Services Administration

Public Buildings Service

Office of Real Property Management and Safety Washington, DC 20405 



\section{A Sprinkler Fire Suppression Algorithm for the GSA Engineering Fire Assessment System}

Daniel Madrzykowski

Robert L. Vettori

May 1992

\section{U.S. Department of Commerce}

Barbara Hackman Franklin, Secretary

Technology Adminstration

Robert M. White, Undersecretary of Technology

National Institute of Standards and Technology

John W. Lyons, Director

Building and Fire Research Laboratory

Gaithersburg, MD 20899
Prepared for:

General Services Administration

Richard G. Austin, Administrator

Public Buildings Service

Milton Herson, Commissioner

Office of Real Property Management and Safety

Washington, D.C. 20405 

Page

LIST OF TABLES . . . . . . . . . . . . . . . . iv

LIST OF FIGURES . . . . . . . . . . . . . . . . . . V

ABSTRACT . . . . . . . . . . . . . . . . 1

1. BACKGROUND . . . . . . . . . . . . . . 2

2. APPROACH . . . . . . . . . . . . . . . . . 2

2.1 SUPPRESSION OF WOOD CRIB FIRES . . . . . . . . . 2

3. EXPERIMENTAL APPROACH . . . . . . . . . . . . . . 3

3.1 SELECTION OF FUEL PACKAGES . . . . . . . . . . . 4

3.2 IGNITION SOURCES ................... . . 4

3.3 HEAT RELEASE RATE MEASUREMENT . . . . . . . . . . 5

3.4 METHOD OF WATER APPLICATION . . . . . . . . . 5

4. TEST PROCEDURE . . . . . . . . . . . . . . . . . . 6

4.1 SOFA FUEL PACKAGE . . . . . . . . . . . . . . 6

4.2 CHAIR FUEL PACKAGE . . . . . . . . . . . . . . . . 7

4.3 OFFICE FUEL PACKAGE . . . . . . . . . . . . . . . . 7

4.4 WORK STATION I FUEL PACKAGE . . . . . . . . . . . 7

4.5 TRASH CART FUEL PACKAGE . . . . . . . . . . . . . 8

4.6 WORK STATION II FUEL PACKAGE . . . . . . . . . . . 8

4.7 PAPER RECYCLING CART FUEL PACKAGE . . . . . . . . . 9

4.8 EXECUTIVE DESK FUEL PACKAGE . . . . . . . . . . . . 9

4.9 OFFICE II FUEL PACKAGE . . . . . . . . . . . . . . . 9

4.10 SECRETARIAL DESK FUEL PACKAGE . . . . . . . . . 9

5. HEAT RELEASE RATE REDUCTION FACTOR FOR FURNISHINGS • - 10

5.1 SPRINKLERED FIRE SUPPRESSION ALGORITHM . . . . 10

6. DISCUSSION . . . . . . . . . . . . . . . . 11

7. CONCLUSIONS . . . . . . . . . . . . . . 12

8. ACKNOWLEDGEMENTS . . . . . . . . . . . . 13

9. REFERENCES .................. 13 
Page

Table 1. Office Fuel Package components . . . . . . . 15

Table 2. Work Station I Fuel Package Components . . . . 16

Table 3. Work Station II Fuel Package components . . . . 17

Table 4. Executive office Fuel Package Components . . . 18

Table 5. Office II Fuel Package Components . . . . . . . 19

Table 6. Secretarial Desk Fuel Package Components . . . 20 


\section{LIST OF FIGURES}

Page

Figure 1. Wooden Crib Fuel Package .. . . . . . .

Figure 2. Heat Release Rate Curves - Wooden Crib Fuel

Package

Figure 3. Normalized Heat Release Rate Curves - Wooden Crib Fuel Package

Figure 4. Typical Test Configuration

Figure 5. Average Water Spray Density . . . . . . . 25

Figure 6. Sofa Fuel Package 26

Figure 7. Heat Release Rate Curves - Sofa Fuel Package.. 27

Figure 8. Office Fuel Package . . . . . . . . . . 28

Figure 9. Heat Release Rate Curves - Office Fuel Package 29

Figure 10. Work Station I Fuel Package . . . . . . . 30

Figure 11. Heat Release Rate curves - Work Station I Fuel Package

Figure 12. Work Station II Fuel Package

Figure 13. Heat Release Rate Curves - Work Station II Fuel Package . . . . . . . . . . . . .

Figure 14. Heat Release Rate Reduction Curves - Paper Recycling Cart, Office II, Executive Desk and Secretarial Desk Fuel Packages . . . . .

Figure 15. Envelope of Normalized Heat Release Rate Curves with HRR Reduction Curve 

A Sprinkler Fire Suppression Algorithm for the GSA Engineering Fire Assessment System

Daniel Madrzykowski

Robert L. Vettori

Building and Fire Research Laboratory

National Institute of Standards and Technology

\section{ABSTRACT}

A study was conducted to develop a sprinkler fire suppression algorithm for use with sprinkler activation time models. Large scale experiments were performed to determine the heat release rate (HRR) of selected office fuel packages with and without sprinklers operating. Eight different fuel packages were evaluated. The results from these experiments were used to develop a time dependent HRR reduction factor.

$$
\begin{aligned}
\text { HRR Reduction Factor }= & e^{-0.0023 t} \\
\text { where: } t= & \text { Time after sprinkler } \\
& \text { activation }(s)
\end{aligned}
$$

The sprinkler fire suppression algorithm consists of multiplying the HRR reduction factor by the HRR at the time of sprinkler activation, $\dot{Q}_{\text {act }}$, yielding an expected upper bound to the HRR at a given time after sprinkler activation, $\dot{Q}(t)$, for office furnishing fires that are not heavily shielded.

$$
\dot{Q}(t)=\dot{Q}_{a c t} e^{-0.0023 t}
$$

This sprinkler fire suppression algorithm can be thought of as a "zeroth order" fire suppression model for "light hazard" occupancies with a sprinkler spray density of $0.07 \mathrm{~mm} / \mathrm{s}(0.1$ $\mathrm{gpm} / \mathrm{ft}^{2}$ ) or greater.

Key words: crib fires; fire suppression; fire tests; fuel load; free burning fires; heat release rate; sprinklers 


\section{BACKGROUND}

The General Services Administration (GSA) has expressed a need for sprinkler design criteria for use in government office spaces which ensure adequate, cost effective fire protection. Under the sponsorship of GSA, the Building and Fire Research Laboratory (BFRL) at the National Institute of standards and Technology (NIST) has conducted several studies related to the use of sprinkler systems in occupancies of interest to GSA. These studies have included 1) demonstrating the applicability of quick response sprinklers in offices[1] ${ }^{1}$, 2) determining the effect of sprinkler sprays on the burning rate of idealized fuels[2], and 3) examining the conditions affecting the operation of sprinklers[3]. Concurrent with these studies, an engineering fire assessment system, FPETOOI[4], has been developed to evaluate hazard and fire protection strategies in GSA buildings. Although this assessment system can be used to evaluate a wide range of conditions, it does not specifically address the benefits of sprinklers. The system is capable of predicting the time of operation of sprinklers. The inclusion of a sprinklered fire suppression calculation in the assessment system would provide a significant advance in capability. The objective of this study was to develop a sprinkler fire suppression algorithm for office furnishings for inclusion in FPETOOL.

\section{APPROACH}

Office furnishings and equipment can be composed of forms of wood, plastic, foam, textiles and any combination thereof. The geometry of most furnishings is such that some surfaces would be exposed to direct impingement from a sprinkler's water spray and other surfaces would be shielded from the water spray. As furnishings may be ignited in various positions, and the initial flame spread is also variable, it is likely that geometry effects could cause a great variation in fire suppression of furnishings. A priori predictions of the reduction of heat release rate (HRR) during suppression of furnishing fires, even if the position of ignition is specified, is well beyond present engineering capabilities. As a first step, a sprinkler fire suppression algorithm that consists of a bounding curve defined by a simple functional form has been developed based on experimental data.

\subsection{SUPPRESSION OF WOOD CRIB FIRES}

In a previous study for GSA, Walton [2] provided information on the reduction in HRR as a function of water spray density on wood crib fires. Wood cribs were used because they provide a repeatable source fire. In addition, portions of cribs are shielded from the

1 Numbers in brackets indicate literature references at the end of the paper. 
water spray, while other portions are fully exposed (Figure 1). Wood cribs are representative of light hazard fuel packages. Figure 2 shows the suppression of fully involved, well ventilated $45 \mathrm{~kg}$ (100 lb) wood crib fires, at six different water spray densities. The two extremes are represented by the non-sprinklered curve, in which no water spray was applied and the $0.126 \mathrm{~mm} / \mathrm{s}$ $\left(0.186 \mathrm{gpm} / \mathrm{ft}^{2}\right)$ water spray density curve which reduced the HRR rate by $60 \%$ within one minute of sprinkler activation.

For purposes of sprinkler system design, an office space is considered a light hazard occupancy by NFPA 13[5]. For calculating water demand this standard specifies a minimum $0.07 \mathrm{~mm} / \mathrm{s}$

$\left(0.1 \mathrm{gpm} / \mathrm{ft}^{2}\right)$ for light hazard occupancies of $135 \mathrm{~m}^{2}$

$\left(1500 \mathrm{ft}^{2}\right)$ or less in floor area.

The HRR curves in Figure 2 for two of the experiments are in the approximate range of this minimum water spray density, $0.066 \mathrm{~mm} / \mathrm{s}$ $\left(0.097 \mathrm{gpm} / \mathrm{ft}^{2}\right)$ and $0.081 \mathrm{~mm} / \mathrm{s}\left(0.119 \mathrm{gpm} / \mathrm{ft}^{2}\right)$. For these crib fires that were in the quasi-steady burning rate period at the time of sprinkler operation, the fire suppression effect of the sprinkler spray on the burning fuel may be characterized by the reduction in $H R R$ relative to $H R R$ at the time of sprinkler activation. By dividing the two data sets listed above by their respective HRR at the time of sprinkler activation and graphing this data on a semi-log chart (Figure 3) it can be seen that they are almost linear, indicating that the HRR after sprinkler activation may be represented by an exponential function of time. Curve fitting the average of the two tests yields the following equation:

$$
\begin{aligned}
& \text { HHR Reduction }=0.73 \times e^{-0.00225\left(t-t_{a c t}\right)} \\
& \text { where: } \begin{aligned}
t_{\text {act }} & =\text { Time at sprinkler } \\
& \text { activation }(s)
\end{aligned}
\end{aligned}
$$

In Figures 2 and $3, t_{\text {act }}$ is equal to 0 .

\section{EXPERIMENTAL APPROACH}

Fuel packages of typical office furnishings and equipment were selected and burned to determine their heat release rate characteristics. Then similar fuel packages were ignited and suppressed with a water spray from a sprinkler to determine the reduction in heat release rate. The ignition scenarios for these fuel packages were based on waste basket fires or improper disposal of smoking materials. 


\subsection{SELECTION OF FUEL PACKAGES}

A physical survey was taken of furnishings at GSA's central office in Washington D.C. Several categories of furnishings or fuel packages were identified. The first category of fuel was made up of sofas and upholstered chairs which were typically found in reception areas or executive suites. The second category of fuel consisted of furnishings of wooden construction; a desk, a reference table and a padded wood frame desk chair. These furnishings were usually complemented by a computer terminal and assorted paper products. This category of fuel is identified as the office scenario. The third category of fuel package was identified as a work station. The work stations were composed of partitions and laminated wood composite work surfaces with metal support structures. An ABS plastic "tub chair", a computer terminal, and a paper product load similar to that used in the office scenario completed the work station fuel package.

It was noted during the building walk through that there was an extensive use of cardboard boxes for file storage under desks and other horizontal work surfaces. This fuel would be shielded from the sprinkler spray. To simulate this condition, four "copier paper cardboard boxes," each containing twenty pounds of paper, were used as a shielded fire load in the office and the work station test scenarios.

The last category of fuel packages was made up of trash carts and paper recycling carts. These four fuel package categories seemed to cover the majority of the furnishings found in the GSA Central office Building.

Similar furnishing items were procured from the GSA surplus center for use in this study. Finding matching furnishings limited the number of experiments which could be performed in some cases. For instance only two sofas could be located which had the same upholstery (i.e., fabric and padding) and the same shape. Comparable desks and tables were of identical construction and finish with the possible exceptions of drawer configuration or leg shape. Comparable chairs and partitions were of identical construction, respectively, with the possible exception of fabric color. Inoperative computer terminals and waste paper were obtained at NIST for use in this study. Loading the furnishings with a paper load representative of that found during the survey yielded a loading of $50.5 \mathrm{~kg} / \mathrm{m}^{2}\left(101 \mathrm{bs} / \mathrm{ft}^{2}\right)$ on the $5.9 \mathrm{~m}^{2}\left(64 \mathrm{ft}^{2}\right)$ load cell.

\subsection{IGNITION SOURCES}

All of the furniture fuel packages were ignited with a natural gas diffusion flame. The burner was a rectangular shaped, open top 
steel box, $250 \mathrm{~mm}$ (9.75 in) long, $185 \mathrm{~mm}$ (7.25 in) wide and $70 \mathrm{~mm}(2.75 \mathrm{in})$ deep. The shell of the burner was filled with sand, covered by a fibrous refractory material and topped with expanded metal. The top of the burner was located $380 \mathrm{~mm}$ (15 in) above the surface of the load platform to represent the height of a trash can. The burner was operated at $50 \mathrm{~kW}$ for 200 seconds to simulate a small trash can fire as defined by Babrauskas $[6,7]$.

The paper recycling cart and the trash cart fuel packages were ignited with an electric match positioned approximately half-way up from the bottom of the cart, in between the bags of paper. This scenario was intended to represent ignition cased by improper disposal of smoking materials.

\subsection{HEAT RELEASE RATE MEASUREMENT}

The tests were performed under an instrumented exhaust hood which provides measurements of heat release rate (Figure 4). The heat release rate is measured by the method of oxygen consumption calorimetry[8]. The method of oxygen consumption calorimetry requires that all of the gaseous combustion products from the burning item flow through a duct where the mass flow rate and the oxygen concentration are measured. In this study, measurements were made at approximately 11 second intervals via a computerized data collection system. A burn was conducted with selected fuel packages to provide heat release rate data without any suppression action for comparison purposes.

\subsection{METHOD OF WATER APPLICATION}

To ensure that the water spray used in the suppression tests was representative of sprinkler sprays found in practice, a commercially available pendent sprinkler head was employed. The sprinkler head deflector was located $2.35 \mathrm{~m}$ (93 in) above the surface of the load platform as if installed below a 2.44 ( $8 \mathrm{ft}$ ) ceiling, except no ceiling was present. The sprinkler's position relative to the fuel packages varied depending on the type of fuel package. The flow from the sprinkler was fixed at $1.6 \times 10^{-3} \mathrm{~m}^{3} / \mathrm{s}$ (25 gpm) for all of the experiments.

To determine the amount and the distribution of the water spray on the load platform, $0.36 \mathrm{~m}$ (14 in) square pans were placed adjacent to one another on the load platform to collect the water spray for a fixed period of time, usually 10 minutes. The amount of water in each pan was measured and recorded to develop a spray density map of the load platform. Areas on the platform had spray densities as low as $0.035 \mathrm{~mm} / \mathrm{s}\left(0.052 \mathrm{gpm} / \mathrm{ft}^{2}\right)$ and as high as $0.13 \mathrm{~mm} / \mathrm{s}$

$\left(0.18 \mathrm{gpm} / \mathrm{ft}^{2}\right)$. It has been shown that sprinkler spray density varies widely $[2,9]$, so it was not surprising to see the lack of uniformity of sprinkler spray density on the load platform.

Figure 5 shows the average and standard deviation of 3 sprinkler spray density measurements. The sprinkler spray density data shown 
was typical of sprinkler spray density tests taken during the duration of the test series. For the fuel package area on the load platform, an average spray density of $0.07 \mathrm{~mm} / \mathrm{s}\left(0.1 \mathrm{gpm} / \mathrm{ft}^{2}\right.$ ) was measured consistently throughout this study. However random variations of local spray density within the area of the load platform were common. It should be noted that spray densities were measured in the absence of any fire, as is common practice. Fire induced gas flows are likely to modify the spray distribution during fire suppression.

\section{TEST PROCEDURE AND RESULTS}

The testing was performed under the main oxygen calorimetry hood at BFRL's large scale test facility. The fuel packages were weighed and positioned on an $2.44 \mathrm{~m} \mathrm{x} 2.44 \mathrm{~m}$ ( $8 \mathrm{ft} \times 8 \mathrm{ft}$ ) load cell platform, which is located under the hood. Several of the fuel packages were burned with no water application to obtain HRR characteristics. Then sprinklered tests were conducted where the burning fuel was subjected to water spray. No attempt was made to simulate the response of a sprinkler to a similar fire in GSA office spaces. The time of sprinkler activation in these experiments was determined from observations during free burn tests and/or the amount of fire involvement during the period before sprinkler activation in the suppression tests. Sufficient pre-burn time was allowed such that each fuel package became well involved with fire and then the sprinkler was manually activated prior to reaching the fuel package's peak heat release rate.

\subsection{SOFA FUEL PACKAGE}

A vinyl covered, polyurethane foam cushioned sofa was chosen as the representative sofa fuel package. The burner was centered, front to back, on one end of the sofa (Figure 6). The outer side of the couch arm next to the burner was consumed within the first 200 seconds. After the burner was removed $(200 \mathrm{~s})$, the fire propagated to the seat and back cushions. The accompanying rapid HRR increase can be seen on Figure 7. At approximately 7 minutes from ignition, one half of the sofa was involved in fire, the HRR was $450 \mathrm{~kW}$. The fire intensity decreased significantly until flames worked their way to the bottom of the sofa. Then the rest of the sofa became involved and the HRR went up to its second peak of $600 \mathrm{~kW}$ at $835 \mathrm{~s}$ (approximately 14 minutes). 21 minutes into the test the sofa collapsed and continued to burn. Data collection was stopped after 35 minutes.

The burn was then repeated with a similar sofa for the suppression measurements. The objective was to activate the sprinkler as close as possible to the first HRR peak and/or when half of the surface area of the sofa was aflame. It was also important to activate the sprinkler during a period of fire growth to insure that the majority of the decrease in HRR was attributable to the sprinklex spray and not to a decrease in available fuel. 
When the second sofa burn reached a peak HRR of $280 \mathrm{~kW}$ the sprinkler was activated. The water extinguished the visible flames on the upper surfaces of the sofa within a matter of seconds. Some small flamelets (less than $150 \mathrm{~mm}$ ( 6 in) in length) continued to burn on the underside of the couch, but the HRR was below the lower limit of the instrumented hood which is approximately $50 \mathrm{~kW}$.

\subsection{CHAIR FUEL PACKAGE}

An upholstered leather chair with blended cotton felt and horse hair padding was used for the second item in the executive furnishings scenario. After the burner was removed, the flame would not sustain itself or propagate on the chair. Hence, the chair was not considered further in this study.

\subsection{OFFICE FUEL PACKAGE}

Descriptions of the items, which composed the office fuel package, and their respective weights are listed in Table 1 . The burner was positioned under the reference table next to the 4 boxes of paper. The gas pipe leading to the burner can be seen under the table in the lower right hand corner of Figure 8. Examining the unsuppressed HRR curve in Figure 9, 4 HRR peaks are found. The first peak is representative of the reference desk and the materials under it. The second peak occurs when the side of the desk adjacent to the reference table is involved and the computer terminal is burning. The third and largest peak of $1.3 \mathrm{MW}$ represents the added involvement of the office chair. The final peak occurs when the desk becomes involved. The package was allowed to burn for more than an hour before being extinguished.

Looking at the two HRR curves for the suppression tests (Figure 9) it is apparent the HRR is substantially higher than the first peak on the unsuppressed HRR curve. The HRR peaked at $1.1 \mathrm{MW}$ in the first sprinklered test and at $950 \mathrm{~kW}$ in the second sprinklered test. This was the result of the computer terminal igniting during the initial growth stage of these fires. When the sprinkler was activated the flames on the top surfaces of the desk and reference table were suppressed within a matter of seconds. However, the materials under the reference table as well as the underside of the reference table and the shielded side of the desk continued to burn. Small flamelets continued to be visible for approximately 30 minutes in both of the suppression tests.

\subsection{WORK STATION I FUEL PACKAGE}

The work station components are listed in Table 2 and shown in Figure 10. The burner was positioned under the side work surface next to four boxes with paper on top of them just as in the office fuel package. Within two minutes after ignition the ABS bucket chair started to burn, resulting in the rapid increase in HRR as shown in Figure 11. Approximately one minute later flames had 
spread to the computer terminal. The fire continued to grow until it reached its peak HRR of $1.7 \mathrm{MW}$ at approximately 300 seconds. The fuel package maintained a HRR in excess of $500 \mathrm{~kW}$ for more than 15 minutes.

For the work station fire suppression tests, the sprinkler was activated at 4 minutes after ignition. The peak HRR in both of the cases was approximately $1.3 \mathrm{MW}$ when the sprinkler was activated. In both cases the paper products on the top surfaces of the desk were extinguished quickly, but the computer terminal and the plastic chair continued to burn, though at a diminished rate. The difference in the HRR between the two suppression tests after the initial HRR reduction was due to the amount of burning material in shielded areas under the desk.

\subsection{TRASH CART FUEL PACKAGE}

The trash cart fuel package consisted of a $0.38 \mathrm{~m}^{3}\left(13.5 \mathrm{ft}^{3}\right)$ polyethylene utility tilt truck loaded with $45.5 \mathrm{~kg}$ (100 lbs) of paper trash. An electric match was inserted in the trash and the contents of the cart was ignited. The trash cart and it's contents burned very slowly. One side of the trash cart began to melt 90 seconds after ignition. The opposite side began to melt 3 minutes after ignition. There were no visible flames above the top of the cart. The cart continued to burn, melt and collapse. The flames were small and close to the fuel surface. The cart burned for more than 30 minutes. The heat release rate for this package was not high enough to be measured accurately under the large instrumented hood. Since this type of fire would offer little if any fire suppression challenge to the sprinkler, this fuel package was not evaluated further.

\section{6 WORK STATION II FUEL PACKAGE}

Work station II had the highest HRR of the fuel packages tested during this study. The components of Work Station II are listed in Table 3. This work station was more enclosed than the work station I fuel package, due to the partial third side partition (Figure 12). The flame spread up the surface of the partition, next to the burner, to ignite the papers on the desk top and eventually spread to the papers and notebooks on the shelf. The fire growth was modest (Figure 13) and appeared to be declining until the shelf collapsed at approximately 5 minutes after ignition. This dropped some of the burning paper into the chair seat and spread paper about the floor near the base of the partition. As the chair fire grew, the HRR rate was driven to the 1 MW range. Fire spread across the interior surfaces of the partitions until the entire work station was involved, reaching a peak HRR of 6.7 MW at approximately 9 minutes after ignition.

The repeat of the fire for the sprinklered case grew in a similar fashion with the shelf collapsing at 225 seconds. The fire spread 
to the chair at 325 seconds and the sprinkler was activated at 360 seconds at a HRR of $700 \mathrm{~kW}$. The majority of the fire was suppressed within 30 seconds of sprinkler activation. Burning continued in the shielded area under the desk for approximately another 10 minutes.

\subsection{PAPER RECYCLING CART FUEL PACKAGE}

The paper recycling cart was an $0.63 \mathrm{~m}^{3}$ (18 bushel) canvas hamper similar to those used by the post office. It was filled with $11.4 \mathrm{~kg}$ (25 lbs) of shredded paper in polyethylene bags. This fuel package was ignited with an "electric match" which was positioned half way up from the bottom of the cart between the bags.

This package had a peak HRR of approximately $700 \mathrm{~kW}$, at the time of sprinkler activation. The sprinkler was activated at 270 seconds after ignition. The majority of the visible flames were extinguished within 1 minute of sprinkler activation. Figure 14 shows the HRR curve post sprinkler activation.

\subsection{EXECUTIVE DESK FUEL PACKAGE}

The components for the executive desk fuel package are listed in Table 4. The significant difference between this package and the office fuel package is the use of two upholstered chairs; a high back executive style chair behind the desk and a pedestal base visitors chair next to the desk. Also no reference table and no "copier paper cardboard boxes" full of files were used in this scenario. The sprinkler was activated at a HRR of $545 \mathrm{~kW}, 900$ seconds after ignition. Since there was very little shielded fuel in this fuel package the HRR decreased rapidly following a trend similar to the paper recycling cart as shown in Figure 14.

\subsection{OFFICE II FUEL PACKAGE}

The office II fuel package is similar to the office I fuel package with the exception of using two computers instead of one, one on the reference table and one on the desk (Table 5). The sprinkler was activated at a HRR of $425 \mathrm{~kW}, 840$ seconds after ignition. The shielded fuel in this scenario delayed the HRR reduction for almost two minutes before the sprinkler spray made a noticeable impact on the HRR (Figure 14).

\subsection{SECRETARIAL DESK FUEL PACKAGE}

The secretarial desk fuel package components are listed in Table 6. In this case the chair was pushed under the desk. This allowed the fire to become well established underneath the desk as well as underneath the side extension where the "copier paper cardboard boxes" were located. The sprinkler was activated at a HRR of $550 \mathrm{~kW}, 240$ seconds after ignition. The fires on the top of the desk (i.e. computer, files, etc) were suppressed within 2 minutes. However, the shielded fire under the horizontal work surfaces 
continued to burn vigorously for approximately another 3 minutes before the HRR began decreasing (Figure 14). The fire did not spread from the shielded area to other portions of the fuel package, hence the fire can be considered to be controlled by the sprinkler.

\title{
5. HEAT RELEASE RATE REDUCTION FACTOR FOR FURNISHINGS
}

The purpose of this study was to develop an empirically based sprinkler fire suppression algorithm. The basis of the algorithm is the HRR curves described in the previous sections. Dividing the sprinklered HRR curve by the HRR at the time of sprinkler activation for each fuel package yields a dimensionless quantity which represents the decreasing HRR with respect to time during suppression. This was done for each fuel package.

The normalized data are shown on a semi-log plot (Figure 15). Walton's wood crib data[2] (Figure 3) is also shown on Figure 15. It can be seen that a majority of the furnishing fire data is bounded by the data for the wood crib. The secretarial desk scenario, which exceeded the curve at times is an exception due to it's heavily shielded fire load and will be addressed in the Discussion section of this paper. Hence, using an exponential decay equation similar to the curve fit equation from the wood cribs and constraining the $y$ intercept to 1 yields the curve shown in Figure 15. Constraining the curve to pass through 1 at $t_{\text {act }}$ allows the upper bound concept to be used any time after sprinkler activation, and it provides some factor of safety. This curve represents the expected upper bound for the reduction of HRR for office furnishing fires at a given time after sprinkler activation and is given by the equation:

\author{
HRR Reduction Factor $=e^{-0.0023 t}$ \\ where: $t=$ Time after sprinkler \\ activation (s)
}

\subsection{SPRINKLERED FIRE SUPPRESSION ALGORITHM}

The sprinkler fire suppression algorithm can be used in the following manner to estimate the reduction of HRR due to sprinkler intervention.

1) Identify the fuel package of concern. Match its description and composition to a fuel package described herein 
or in other references containing fuel package descriptions and their associated HRR curves i.e., $[1,4,10]$. Another option is to choose a " $t^{2}$ fire" representative of your fuel package.

2) Utilizing the HRR curve from step 1 run a sprinkler activation program. Let the time of sprinkler activation equal $t_{\text {act }}$.

3) To find the HRR after sprinkler activation at a given time, $t$, let

$$
\Delta t=t-t_{a c t}
$$

Substituting $\Delta t$ into HRR reduction factor equation will yield the HRR reduction factor at that time. Multiplying the HRR at sprinkler activation, $\dot{Q}_{\text {act }}$, by the HRR reduction factor gives the estimated upper bound to the HRR at that time after sprinkler activation.

$$
\dot{Q}(\Delta t)=\dot{Q}_{a c t} e^{-0.0023 \Delta t}
$$

4) Step 3 can be repeated at several different times after sprinkler activation to develop a HRR reduction curve for the given fuel package during sprinklered fire suppression.

A subroutine is being developed for the GSA Engineering Fire Assessment system [4] to perform this calculation.

\section{DISCUSSION}

The HRR reduction factor constitutes a "zeroth order" fire suppression model. As with most models, certain assumptions and Iimitations must be considered when applying this model. The tests upon which this model was based were all burned in the open i.e. no compartment effects. There are potential phenomena in a compartment which could effect the reduction of heat release rate of the fire.

The water spray density is assumed to be at least $0.07 \mathrm{~mm} / \mathrm{s}$ $\left(0.1 \mathrm{gpm} / \mathrm{ft}^{2}\right)$. A previous study[2] has shown the effect of reducing the water spray density. Such reduction can dramatically increase the time required to control a fire or if the density is too low, the ability to control the fire can be lost.

The tests were conducted with a broad cross section of office furnishings. In Figure 15 the exponential HRR reduction curve is 
shown to bound most of the experimental data, with the noticeable exception of the secretarial desk test. The measured HRR of the secretarial desk exceeded portions of the bounding HRR reduction curve. This was a scenario where shielded fuels were heavily involved with fire prior to and after sprinkler operation. Even though the HRR rate increased or remained high after sprinkler operation, the fire did not spread outside of the shielded area. Fuel load geometry is clearly one of the limitations of this and many other models. Efforts were made to overcome this limitation by basing the HRR reduction factor on test data. However, if the HRR reduction curve were based solely on heavily shielded fires such as the secretarial desk it would be much too conservative for the majority of the other test cases. Further, activation of more than one sprinkler head would mitigate the adverse impact of shielding on fire suppression.

This algorithm provides the user with a tool to predict sprinklered fire suppression for potential office fire situations. Fire suppression prediction could be improved and generalized by further research into the effect of compartments on suppression of fires and fuel packages for different classes of occupancy with different water spray density requirements. This model addresses the impact of the sprinkler on the HRR of the fire, additional research is needed to evaluate other effects such as sprinklered cooling of the fire gases and sprinklered cooling of compartment surfaces.

\section{CONCLUSIONS}

An empirically based sprinklered fire suppression methodology was developed from the measured HRRs of eight different fuel packages during fire suppression experiments. The reduction in HRR under suppression conditions was found to be bounded by an exponential function of time.

HRR Reduction Factor $=e^{-0.0023 t}$

where: $t$ = Time after sprinkler activation (s)

Multiplying the HRR reduction factor by the HRR at the time of sprinkler activation, $\dot{Q}_{\text {act }}$, yields an expected upper bound to the HRR at a given time after sprinkler activation for office furnishing fires that are not heavily shielded.

$$
\dot{Q}(t)=\dot{Q}_{a c t} e^{-0.0023 t}
$$


Calculating this value at different times after sprinkler activation will provide a bounding HRR reduction curve for the office furnishings in question. The sprinkler effectiveness methodology can be thought of as a "zeroth order" fire suppression model, for "light hazard" occupancies with a sprinkler spray density of $0.07 \mathrm{~mm} / \mathrm{s}\left(0.1 \mathrm{gpm} / \mathrm{ft}^{2}\right)$ or greater.

\section{ACKNOWLEDGEMENTS}

Appreciation is extended to L. Delauter, J. McElroy, R. McLane, G. Roadarmel and R. Zile of the Building and Fire Research Laboratory for their assistance in performing this study. Appreciation is also extended to D. Bathurst, D. Frable and D. stroup of GSA for their support of this project.

\section{REFERENCES}

1. Walton, W.D. and Budnick, E.K., Quick Response sprinklers in Office Configurations: Fire Test Results. Nat. Bur. Stand. (U.S.) NBSIR 88-3695; January 1988 .

2. Walton, W.D., Suppression of Wood Crib Fires with Sprinkler Sprays: Test Results. Nat. Bur. Stand. (U.S.) NBSIR 88-3696; January 1988 .

3. Walton, W.D., Nat. Inst. Stand. Tech. (U.S), to be published.

4. Nelson, H.E., FPETOOL: Fire Protection Tools for Hazard Estimation. Nat. Inst. Stand. Tech. (U.S.) NISTIR 4380 ; October 1990.

5. NFPA 13, Standard for the Installation of sprinkler Systems, 1991 Ed. National Fire Protection Association, Quincy, MA.

6. Babrauskas, V., will the second Item Ignite? Fire Safety Journal, 4 (1981/1982), pp 281-292

7. Babrauskas, V., Lawson, J.R., Walton, W.D., and Twilley, W.H., Upholstered Furniture Heat Release Rates Measured with a Furniture Calorimeter. Nat. Bur. Stand.(U.S.) NBSIR 82-2604; December 1982 .

8. Parker, W.J., Calculation of the Heat Release Rate by Oxygen Consumption for Various Applications. Nat. Bur. Stand. (U.S.) NBSIR 81-2427-1; March 1982 .

9. Beyler, C.L., The Effects of Selected Variables on the Distribution of Water from Automatic Sprinklers, Volume 1: Analysis. Univ. of Maryland, Dept of Fire Prot. Engr.; 1977. 
10. Gross, D., Data Sources for Parameters Used in Predictive Modeling of Fire Growth and Smoke Spread. Nat. Bur. Stand. (U.S.) NBSIR 85-3223; September 1985. 
Table 1. Office Fuel Package Components

\begin{tabular}{|c|c|}
\hline \multicolumn{2}{|l|}{ OFFICE } \\
\hline Item Description (cm) & Mass (kg) \\
\hline Wooden Desk $152 \times 76 \times 76 \mathrm{~h}$ & 92.3 \\
\hline $\begin{array}{l}\text { Wooden Reference Table } \\
152 \text { X } 864 \text { X } 78 \mathrm{~h}\end{array}$ & 46.8 \\
\hline Padded Chair with Wooden Frame & 29.5 \\
\hline Computer Terminal with Keyboard & 15.5 \\
\hline $\begin{array}{c}\text { Box with Paper } 46 \text { X } 29 \times 24 \\
\text { (4 at } 9.1 \mathrm{~kg} \text { each) }\end{array}$ & 36.4 \\
\hline $\begin{array}{c}\text { Computer Paper } \\
(9.1 \mathrm{~kg} \text { on Boxes, } 22.7 \mathrm{~kg} \text { on } \\
\text { Table) }\end{array}$ & 31.8 \\
\hline 3 Phone Books & 2.3 \\
\hline Newspaper & 0.9 \\
\hline Publications & 2.3 \\
\hline Paper for Notebooks \& Files & 29.5 \\
\hline Notebooks \& Files & 3.6 \\
\hline TOTAL & 290.9 \\
\hline
\end{tabular}


Table 2. Work Station I Fuel Package Components

\begin{tabular}{|c|c|}
\hline \multicolumn{2}{|l|}{ WORK STATION I } \\
\hline Item Description (cm) & Mass $(\mathrm{kg})$ \\
\hline $\begin{array}{l}\text { Wooden Desk with Metal Frame } \\
152 \times 610 \times 76 \mathrm{~h} \\
\text { Side Extension for Desk } \\
91 \times 46 \times 46 \mathrm{~h}\end{array}$ & 114.1 \\
\hline $\begin{array}{c}\text { ABS Bucket Chair, Padded with } \\
\text { Metal Pedestal }\end{array}$ & 16.4 \\
\hline Computer Terminal with Keyboard & 15.4 \\
\hline $\begin{array}{c}\text { Partition } 152 \times 2.5 \times 165 \mathrm{~h} \\
\text { cloth Covered, Fiberglass Core, } \\
\text { Metal Structure } \\
(2 \text { at } 23.6 \mathrm{~kg} \text { each })\end{array}$ & 47.3 \\
\hline $\begin{array}{c}\text { Box with Paper } 46 \times 29 \times 24 \\
\text { (4 at } 9.1 \mathrm{~kg} \text { each) }\end{array}$ & 36.4 \\
\hline $\begin{array}{c}\text { Computer Paper } \\
(9.1 \mathrm{~kg} \text { on Boxes, } 13.6 \mathrm{~kg} \text { on } \\
\text { Table) }\end{array}$ & 22.7 \\
\hline 3 Phone Books & 2.3 \\
\hline Newspaper & 0.9 \\
\hline Publications & 2.3 \\
\hline Paper for Notebooks \& Files & 29.5 \\
\hline Notebooks \& Files & 3.6 \\
\hline TOTAL & 290.9 \\
\hline
\end{tabular}


Table 3. Work Station II Fuel Package Components

\begin{tabular}{|c|c|}
\hline \multicolumn{2}{|c|}{ WORK STATION II } \\
\hline Item Description (cm) & Mass (kg) \\
\hline $\begin{array}{l}\text { Covered Particle Board work } \\
\text { Surface with Metal Supports } \\
\qquad 183 \times 610 \times 76 \mathrm{~h}\end{array}$ & 58.2 \\
\hline $\begin{array}{c}\text { ABS Bucket Chair, Padded with } \\
\text { Steel Pedestal }\end{array}$ & 15.9 \\
\hline Computer Terminal with Keyboard & 15.5 \\
\hline $\begin{array}{c}\text { Partitions: } \\
889 \times 2.5 \times 168 \mathrm{~h} \text { (2) } \\
119 \times 2.5 \times 168 \mathrm{~h}(1) \\
58 \times 2.5 \times 168 \mathrm{~h}(1) \\
\text { cloth Covered, Fiberglass core, } \\
\text { Metal Structure }\end{array}$ & $103 \cdot 6$ \\
\hline $\begin{array}{c}\text { Box with Paper } 46 \text { X } 29 \times 24 \\
(4 \text { at } 9.1 \mathrm{~kg} \text { each) }\end{array}$ & 36.4 \\
\hline $\begin{array}{c}\text { Computer Paper } \\
(9.1 \mathrm{~kg} \text { on Boxes, } 13.6 \mathrm{~kg} \text { on } \\
\text { Table) }\end{array}$ & 22.7 \\
\hline 3 Phone Books & 2.3 \\
\hline Newspaper & 0.9 \\
\hline Publications & 2.3 \\
\hline Paper for Notebooks \& Files & 29.5 \\
\hline Notebooks \& Files & 3.6 \\
\hline TOTAL & 290.9 \\
\hline
\end{tabular}


Table 4. Executive Office Fuel Package Components

\begin{tabular}{||c|c||}
\hline \multicolumn{2}{|c||}{ EXECUTIVE OFFICE } \\
\hline Item Description (cm) & Mass (kg) \\
\hline Wooden Desk 152 X 864 X 76h & 89.1 \\
\hline $\begin{array}{c}\text { High Back Executive Chair } \\
\text { Polyurethane Foam Padded with } \\
\text { Metal Frame }\end{array}$ & 18.6 \\
\hline $\begin{array}{c}\text { Upholstered Pedestal Chair, } \\
\text { Neoprene Padding With Wooden } \\
\text { Frame and Metal Pedestal }\end{array}$ & 19.5 \\
\hline $\begin{array}{c}\text { Computer Terminal with Keyboard } \\
\text { Computer Paper }\end{array}$ & 14.1 \\
\hline Paper for Notebooks \& Files & 9.1 \\
\hline \hline TOTAL & 165.9 \\
\hline
\end{tabular}


Table 5. Office II Fuel Package Components

\begin{tabular}{|c|c|}
\hline \multicolumn{2}{|l|}{ OFFICE II } \\
\hline Item Description (cm) & Mass $(\mathrm{kg})$ \\
\hline Wooden Desk $152 \times 864 \times 76 \mathrm{~h}$ & 102.3 \\
\hline $\begin{array}{l}\text { Wooden Reference Table } \\
152 \text { X } 76 \text { × } 79 \mathrm{~h}\end{array}$ & $42 \cdot 3$ \\
\hline Padded Chair with Wooden Frame & 24.5 \\
\hline $\begin{array}{c}\text { Computer Terminal with Keyboard } \\
\text { (2) }\end{array}$ & 26.8 \\
\hline $\begin{array}{c}\text { Box with Paper } 46 \text { X } 29 \times 24 \\
\text { (4 at } 9.1 \mathrm{~kg} \text { each) }\end{array}$ & 36.4 \\
\hline $\begin{array}{c}\text { Computer Paper } \\
(9.1 \mathrm{~kg} \text { on Boxes, } 13.6 \mathrm{~kg} \text { on } \\
\text { Table) }\end{array}$ & 22.7 \\
\hline $\begin{array}{l}\text { Cardboard Paper Recycling Box } \\
30 \mathrm{x} 30 \mathrm{x} 69 \mathrm{~h}, 18 \mathrm{~cm} \text { diameter hole } \\
\text { in lid, Loose paper dropped in } \\
\text { until } 2 / 3 \text { full }\end{array}$ & 6.8 \\
\hline Newspaper & 0.9 \\
\hline Publications & 1.8 \\
\hline Paper for Notebooks \& Files & 29.5 \\
\hline Notebooks \& Files & 3.6 \\
\hline TOTAL & 297.6 \\
\hline
\end{tabular}


Table 6. Secretarial Desk Fuel Package Components

\begin{tabular}{|c|c|}
\hline \multicolumn{2}{|l|}{ SECRETARIAL DESK } \\
\hline Item Description (cm) & Mass $(\mathrm{kg})$ \\
\hline $\begin{array}{l}\text { Wooden Desk with Metal Frame } \\
152 \times 61 \times 76 \mathrm{~h} \\
\text { side Extension for Desk } \\
91 \times 46 \times 46 \mathrm{~h}\end{array}$ & 110.0 \\
\hline $\begin{array}{c}\text { Wood framed chair with foam } \\
\text { padded seat and back, secretarial } \\
\text { type }\end{array}$ & 14.1 \\
\hline Computer Terminal with Keyboard & 15.5 \\
\hline $\begin{array}{c}\text { Partition } 152 \times 2.5 \times 152 \mathrm{~h} \\
\text { cloth Covered, Fiberglass Core, } \\
\text { Metal Structure }\end{array}$ & 21.4 \\
\hline $\begin{array}{c}\text { Box with Paper } 46 \times 29 \times 24 \\
(4 \text { at } 9.1 \mathrm{~kg} \text { each) }\end{array}$ & 36.4 \\
\hline $\begin{array}{c}\text { Computer Paper } \\
(9.1 \mathrm{~kg} \text { on Boxes, } 13.6 \mathrm{~kg} \text { on } \\
\text { Table) }\end{array}$ & 22.7 \\
\hline 3 Phone Books & 2.3 \\
\hline Newspaper & 0.9 \\
\hline Publications & 2.3 \\
\hline Paper for Notebooks \& Files & 29.5 \\
\hline Notebooks \& Files & 3.6 \\
\hline TOTAL & 258.6 \\
\hline
\end{tabular}




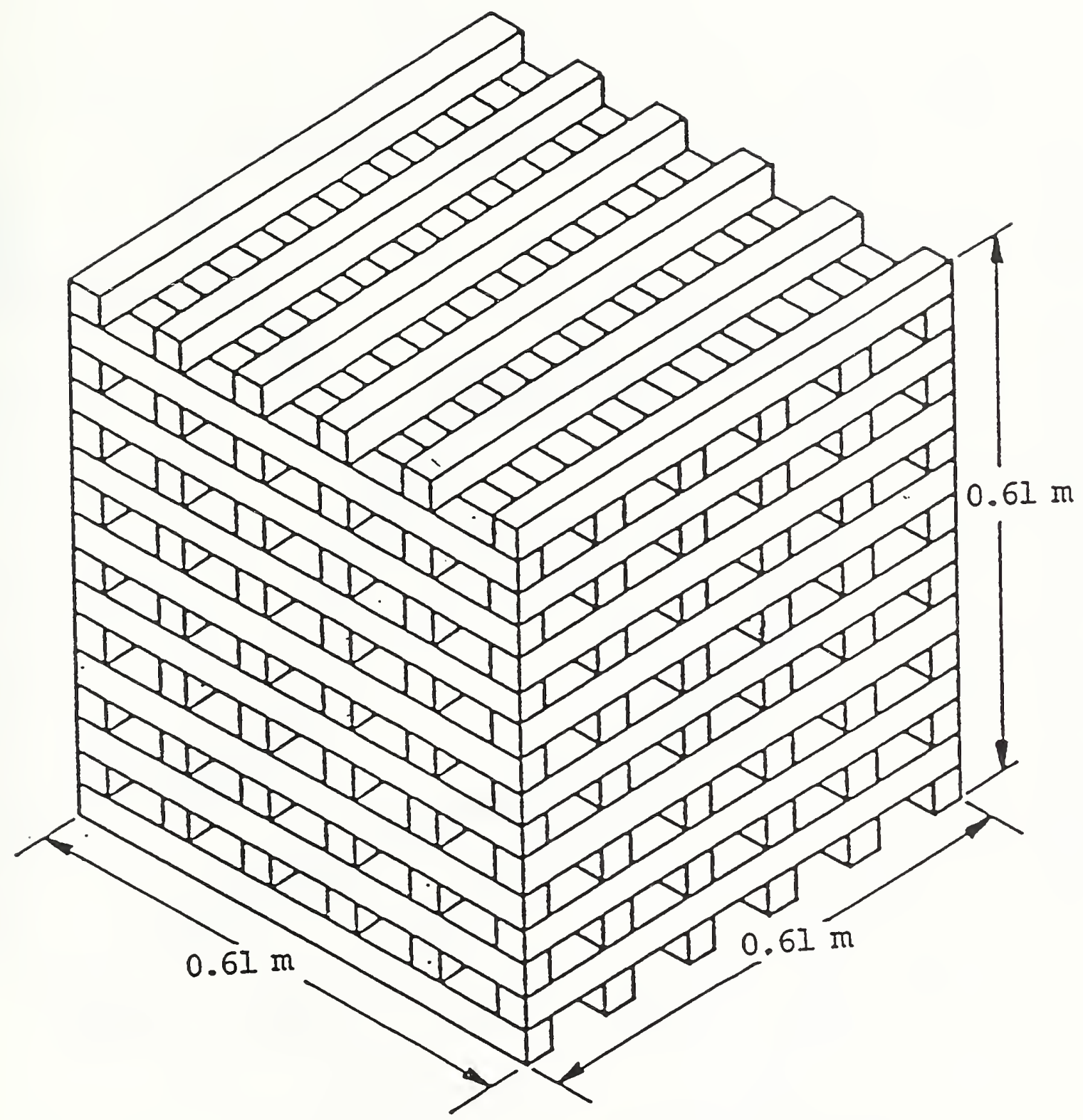

Stick dimensions are approximately $3.8 \mathrm{~cm} \times 3.8 \mathrm{~cm} \times 61 \mathrm{~cm}$.

Figure 1. Wooden Crib Fuel Package 


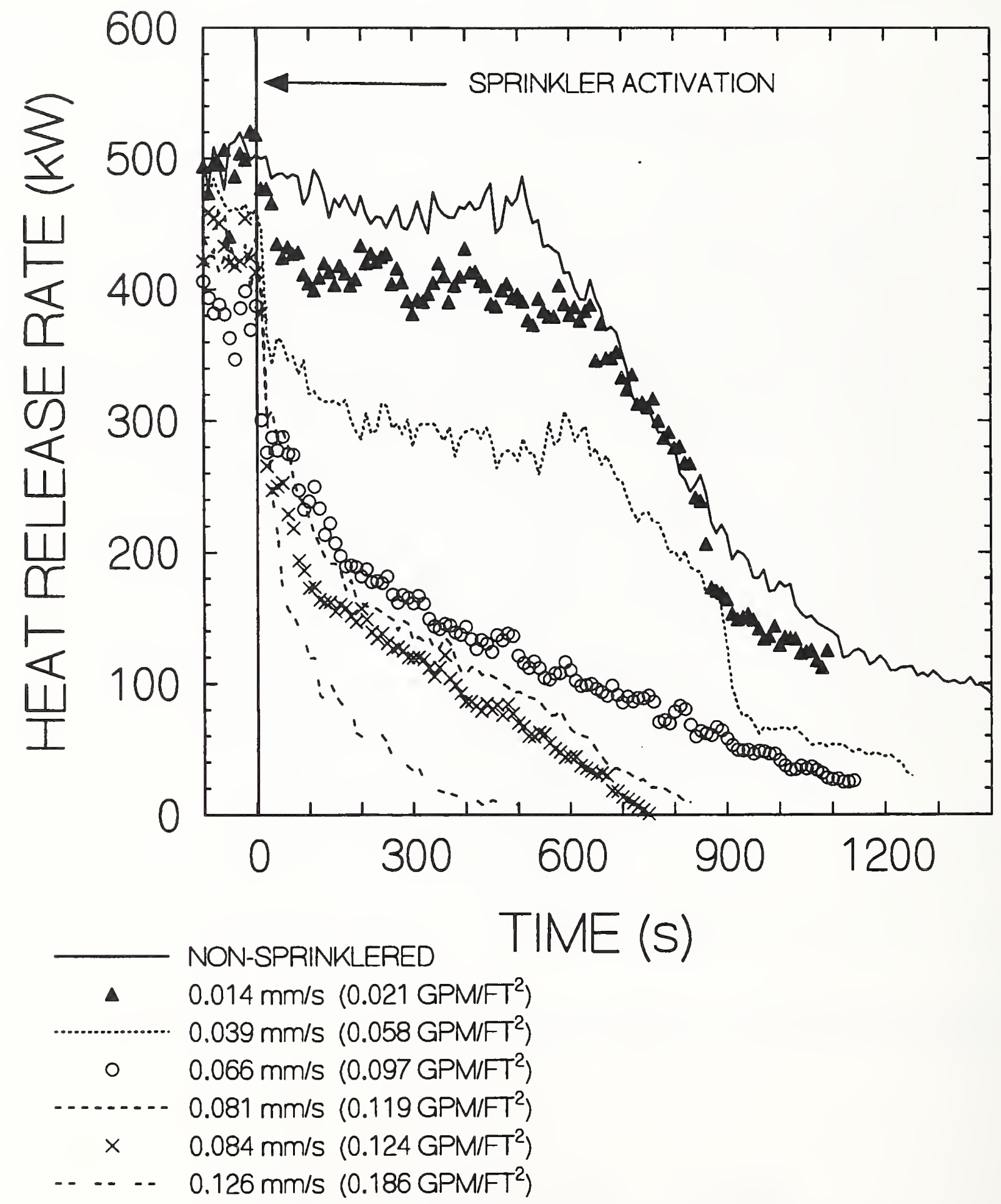

Figure 2. Heat Release Rate Curves - Wooden Crib Fuel Package 

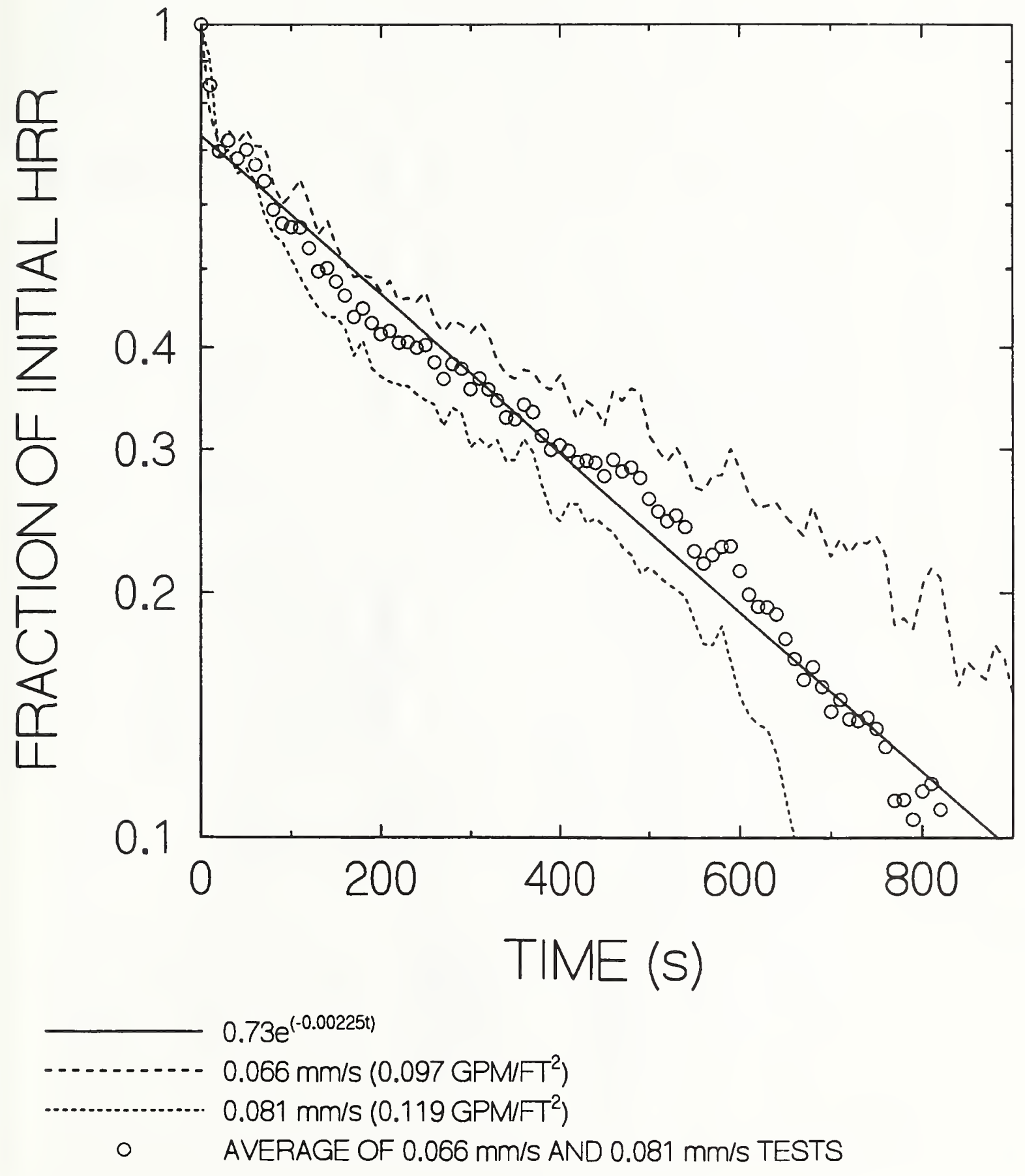

Figure 3. Normalized Heat Release Rate Curves - Wooden Crib Fuel Package 

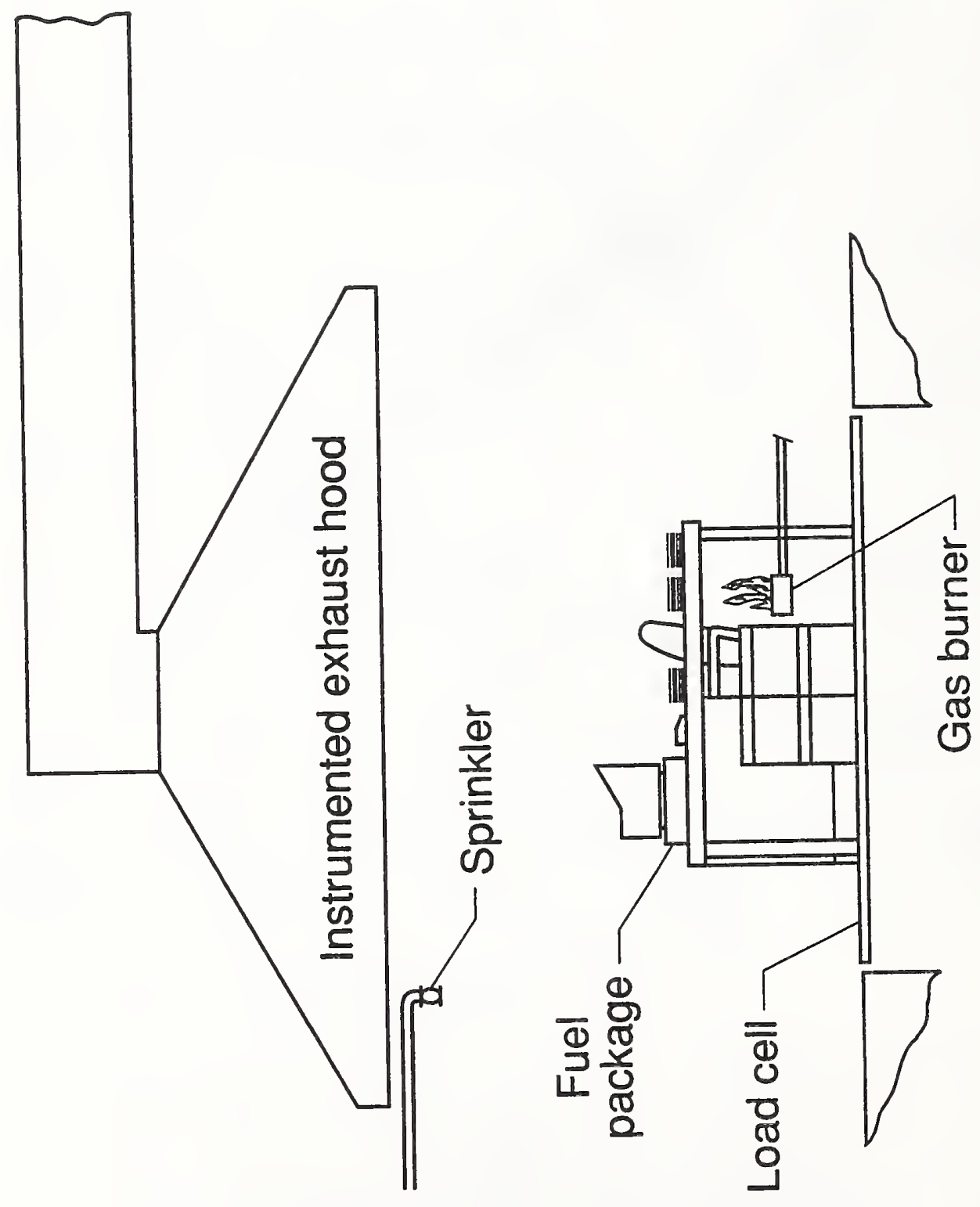

 


\begin{tabular}{|c|c|c|c|c|c|c|c|c|c|}
\hline $\begin{array}{l}0 \\
\overline{8} \\
0 \\
0 \\
+1 \\
+1 \\
\overrightarrow{0} \\
0 \\
0\end{array}$ & 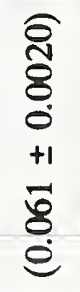 & $\begin{array}{l}\text { 亏े } \\
\text { ठ } \\
0 \\
+1 \\
\vec{n} \\
\stackrel{5}{0}\end{array}$ & 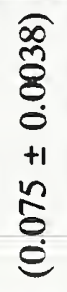 & 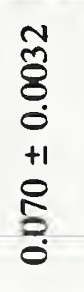 & 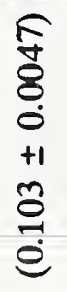 & $\begin{array}{l}\stackrel{్}{8} \\
8 \\
0 \\
+1 \\
+1 \\
\stackrel{0}{0} \\
0 \\
0\end{array}$ & $\begin{array}{l}\text { ले } \\
\hat{\delta} \\
0 \\
+1 \\
\overrightarrow{0} \\
\overrightarrow{0}\end{array}$ & 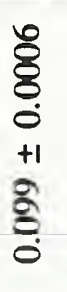 & 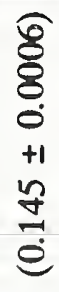 \\
\hline $\begin{array}{l}8 \\
8 \\
8 \\
0 \\
+1 \\
+1 \\
\stackrel{0}{0} \\
0\end{array}$ & $\begin{array}{l}\widehat{J} \\
\stackrel{\Xi}{8} \\
0 \\
+1 \\
\infty \\
0 \\
0 \\
0\end{array}$ & $\begin{array}{l}\tilde{N} \\
\tilde{0} \\
0 \\
0 \\
+1 \\
0 \\
0 \\
0 \\
0\end{array}$ & $\begin{array}{l}\sqrt{n} \\
\tilde{8} \\
0 \\
+1 \\
\hat{n} \\
0 \\
0\end{array}$ & 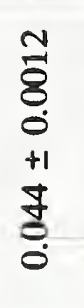 & 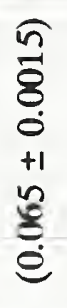 & $\begin{array}{l}n \\
\tilde{8} \\
0 \\
+1 \\
\tilde{n} \\
\varrho \\
0\end{array}$ & 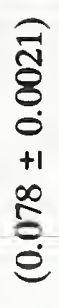 & $\begin{array}{l}0 \\
8 \\
8 \\
0 \\
+1 \\
\stackrel{1}{0} \\
\stackrel{0}{0}\end{array}$ & $\begin{array}{l}\sqrt{n} \\
\overline{8} \\
0 \\
+1 \\
8 \\
8 \\
0 \\
0\end{array}$ \\
\hline $\begin{array}{l}\overrightarrow{0} \\
\hat{8} \\
0 \\
+1 \\
\hat{n} \\
0 \\
0\end{array}$ & 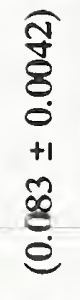 & $\begin{array}{l}0 \\
\tilde{\delta} \\
0 \\
0 \\
+1 \\
-1 \\
0 \\
0\end{array}$ & $\begin{array}{l}\widetilde{n} \\
\tilde{\delta} \\
0 \\
0 \\
+1 \\
n \\
0 \\
0 \\
0\end{array}$ & $\begin{array}{l}\overrightarrow{\widetilde{\sigma}} \\
\stackrel{8}{0} \\
+1 \\
\overrightarrow{0} \\
\dot{0}\end{array}$ & $\begin{array}{l}\widetilde{n} \\
\tilde{\delta} \\
0 \\
0 \\
+1 \\
0 \\
0 \\
0 \\
0\end{array}$ & $\begin{array}{l}\text { \& } \\
8 \\
0 \\
0 \\
+1 \\
0 \\
\stackrel{0}{0} \\
0\end{array}$ & $\begin{array}{l}\widehat{0} \\
8 \\
8 \\
0 \\
0 \\
+1 \\
0 \\
0 \\
0 \\
0\end{array}$ & 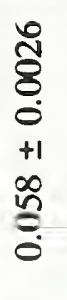 & $\begin{array}{l}\widehat{T} \\
8 \\
8 \\
0 \\
+1 \\
0 \\
0 \\
0 \\
0 \\
0\end{array}$ \\
\hline $\begin{array}{l}n \\
\overline{8} \\
0 \\
+1 \\
+1 \\
0 \\
8 \\
0 \\
0\end{array}$ & 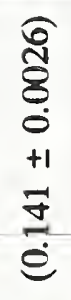 & 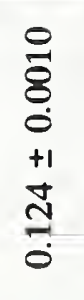 & 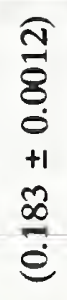 & $\begin{array}{l}\overline{\widetilde{\delta}} \\
0 \\
0 \\
+1 \\
0 \\
\vdots \\
0\end{array}$ & 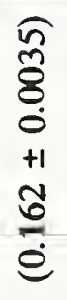 & 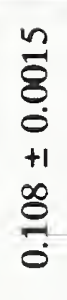 & 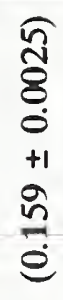 & 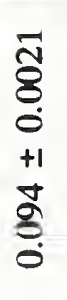 & 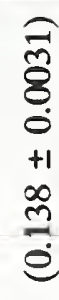 \\
\hline $\begin{array}{l}n \\
\tilde{8} \\
0 \\
+1 \\
\tilde{\sigma} \\
气 \\
0\end{array}$ & 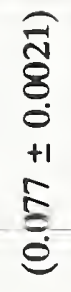 & 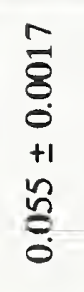 & $\begin{array}{l}\widehat{\widehat{त}} \\
\hat{\delta} \\
0 \\
+1 \\
+1 \\
\stackrel{0}{0} \\
\stackrel{0}{0}\end{array}$ & $\begin{array}{l}8 \\
8 \\
8 \\
0 \\
0 \\
+1 \\
+ \\
\text { ¿े } \\
0\end{array}$ & 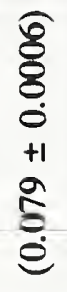 & $\begin{array}{l}\stackrel{0}{8} \\
8 \\
0 \\
+1 \\
+1 \\
\stackrel{0}{0} \\
0\end{array}$ & $\begin{array}{l}0 \\
0 \\
0 \\
0 \\
0 \\
+1 \\
0 \\
0 \\
0 \\
0\end{array}$ & 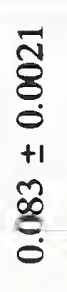 & 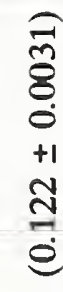 \\
\hline $\begin{array}{l}0 \\
8 \\
8 \\
0 \\
0 \\
+1 \\
+1 \\
0 \\
0 \\
0 \\
0\end{array}$ & 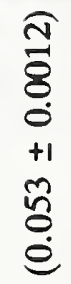 & $\begin{array}{l}8 \\
\delta \\
\delta \\
0 \\
0 \\
+1 \\
0 \\
0 \\
0 \\
0\end{array}$ & $\begin{array}{l}\widehat{8} \\
8 \\
8 \\
0 \\
+1 \\
+\infty \\
\infty \\
0 \\
0 \\
0\end{array}$ & $\begin{array}{l}0 \\
\stackrel{0}{8} \\
0 \\
0 \\
+1 \\
\vec{n} \\
0 \\
0 \\
0\end{array}$ & $\begin{array}{l}\widetilde{n} \\
\tilde{8} \\
0 \\
0 \\
+1 \\
n \\
0 \\
0 \\
0\end{array}$ & 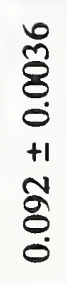 & $\begin{array}{l}\widehat{0} \\
\stackrel{2}{8} \\
0 \\
0 \\
+1 \\
0 \\
0 \\
0 \\
0\end{array}$ & 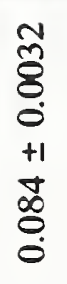 & 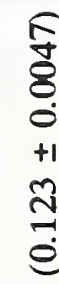 \\
\hline
\end{tabular}




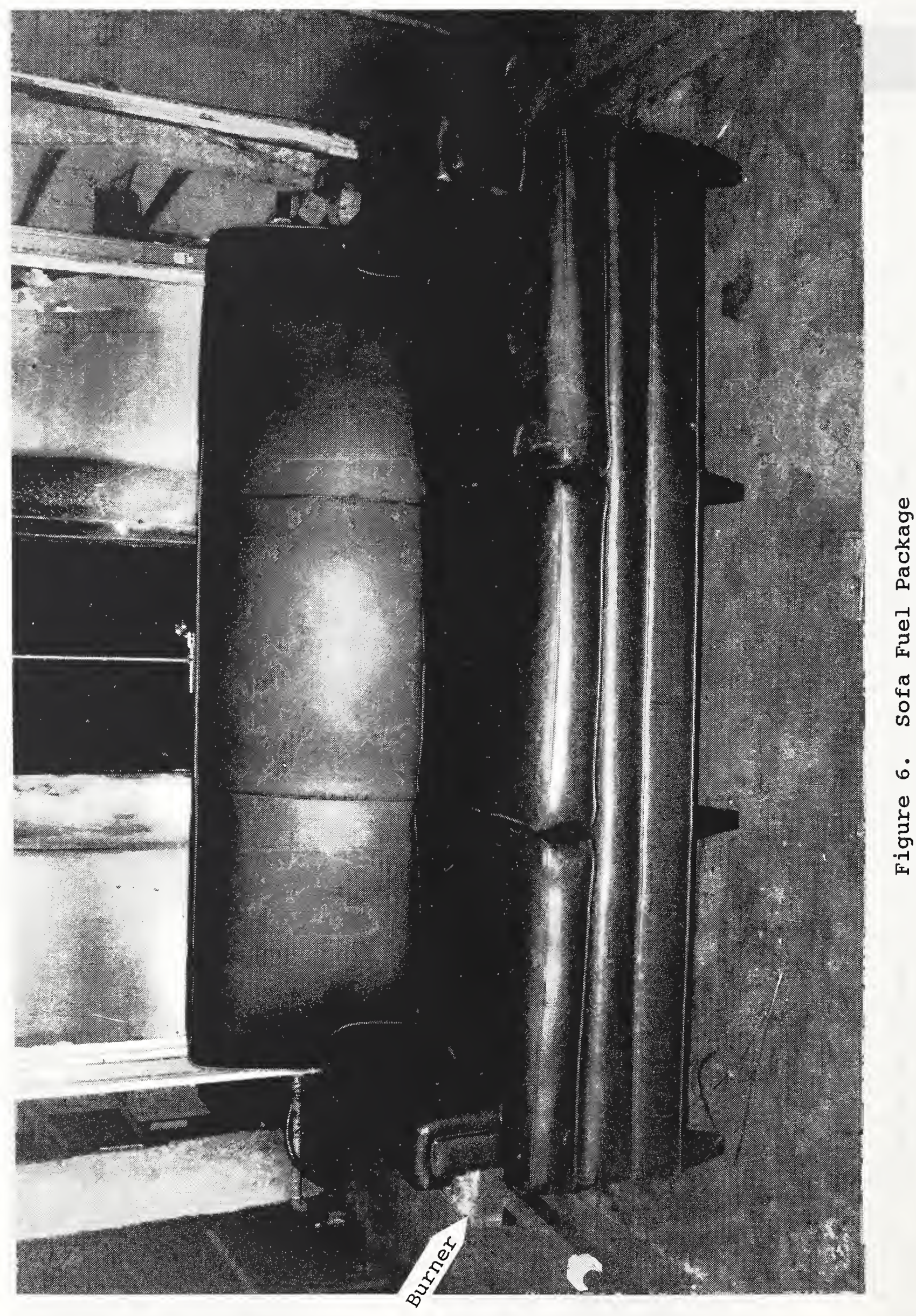




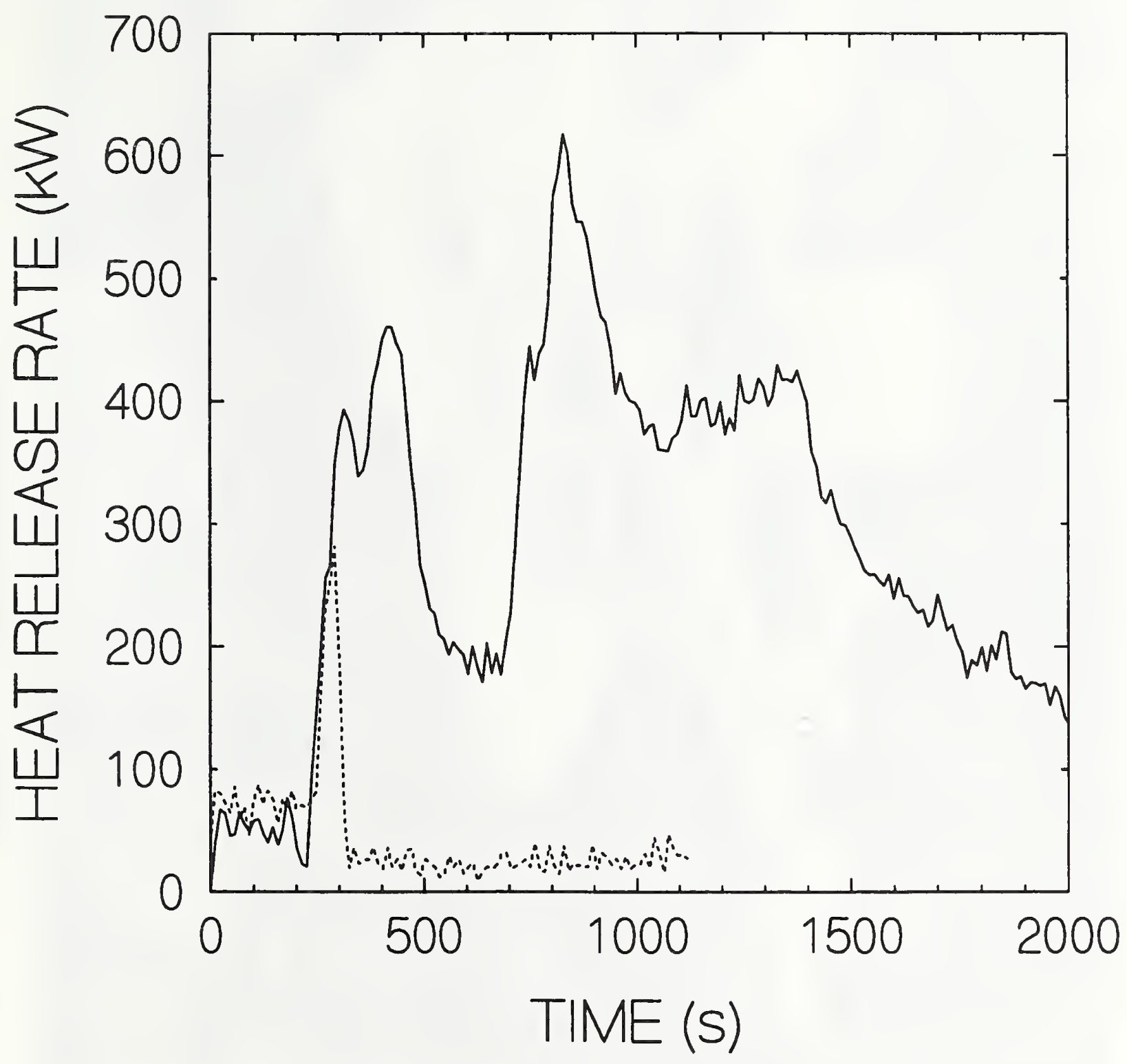

NON-SPRINKLERED SPRINKLERED

Figure 7. Heat Release Rate Curves - Sofa Fuel Package 


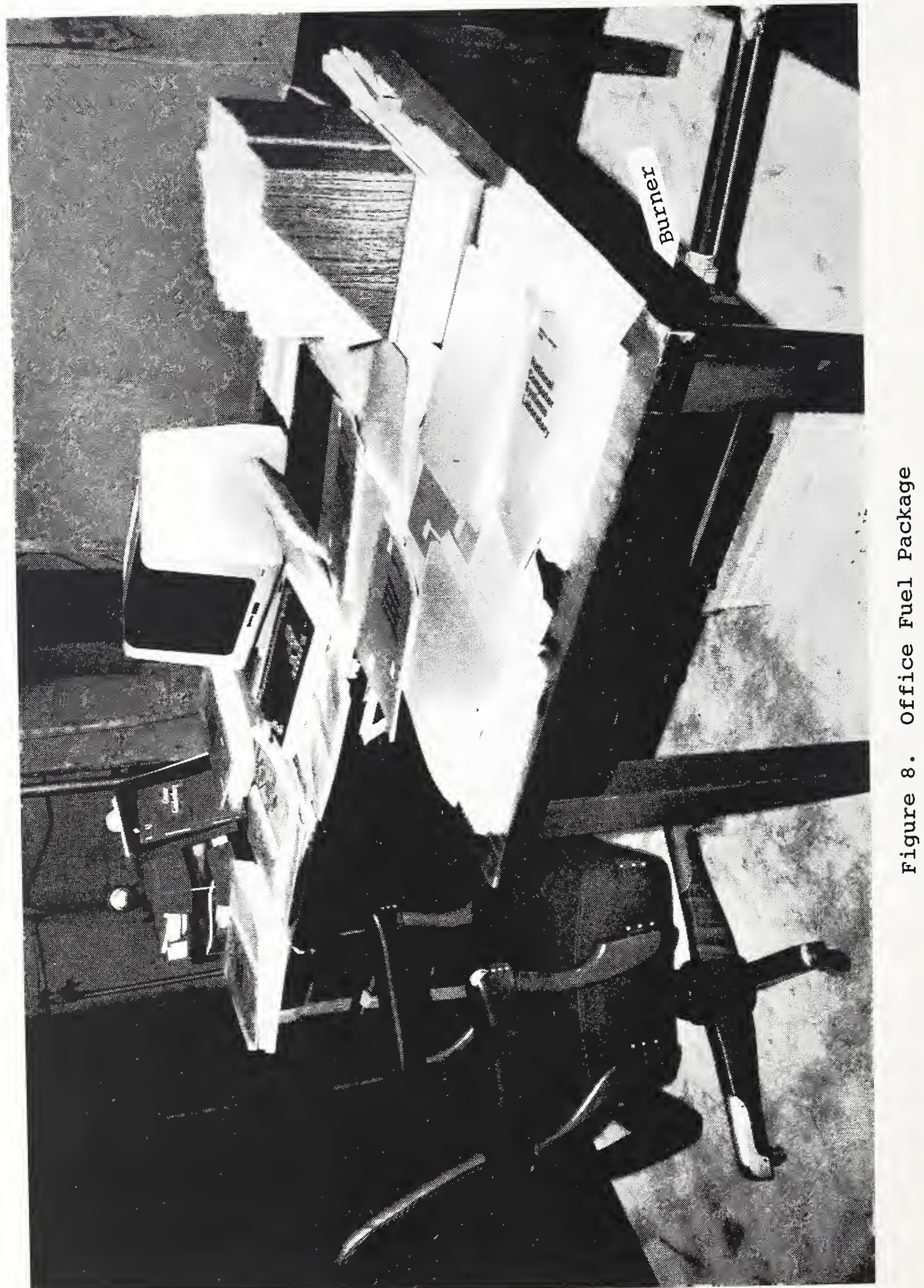




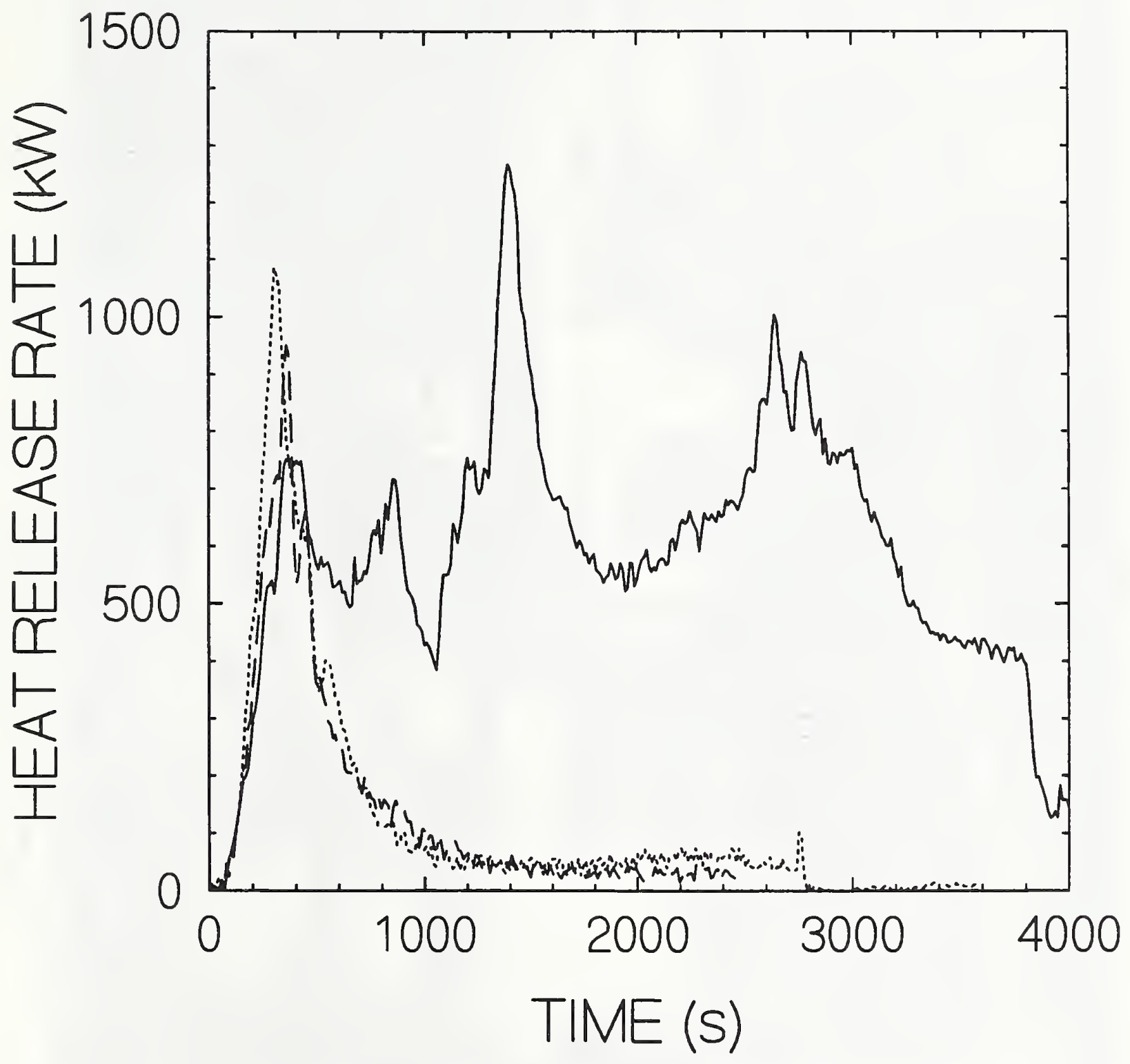

NON-SPRINKLERED

SPRINKLERED

- - - SPRINKLERED (REPLICATE)

Figure 9. Heat Release Rate curves - Office Fuel Package 


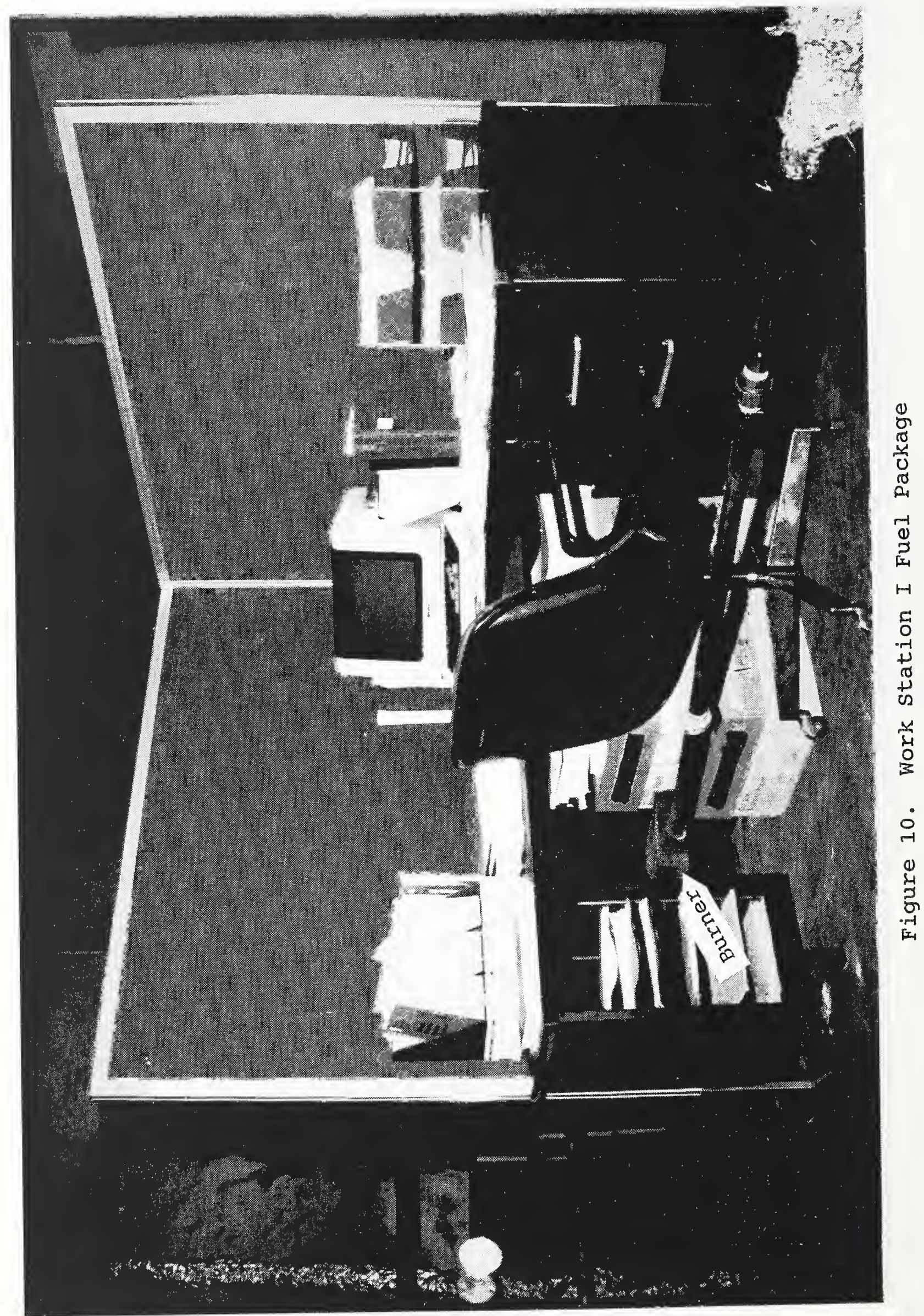




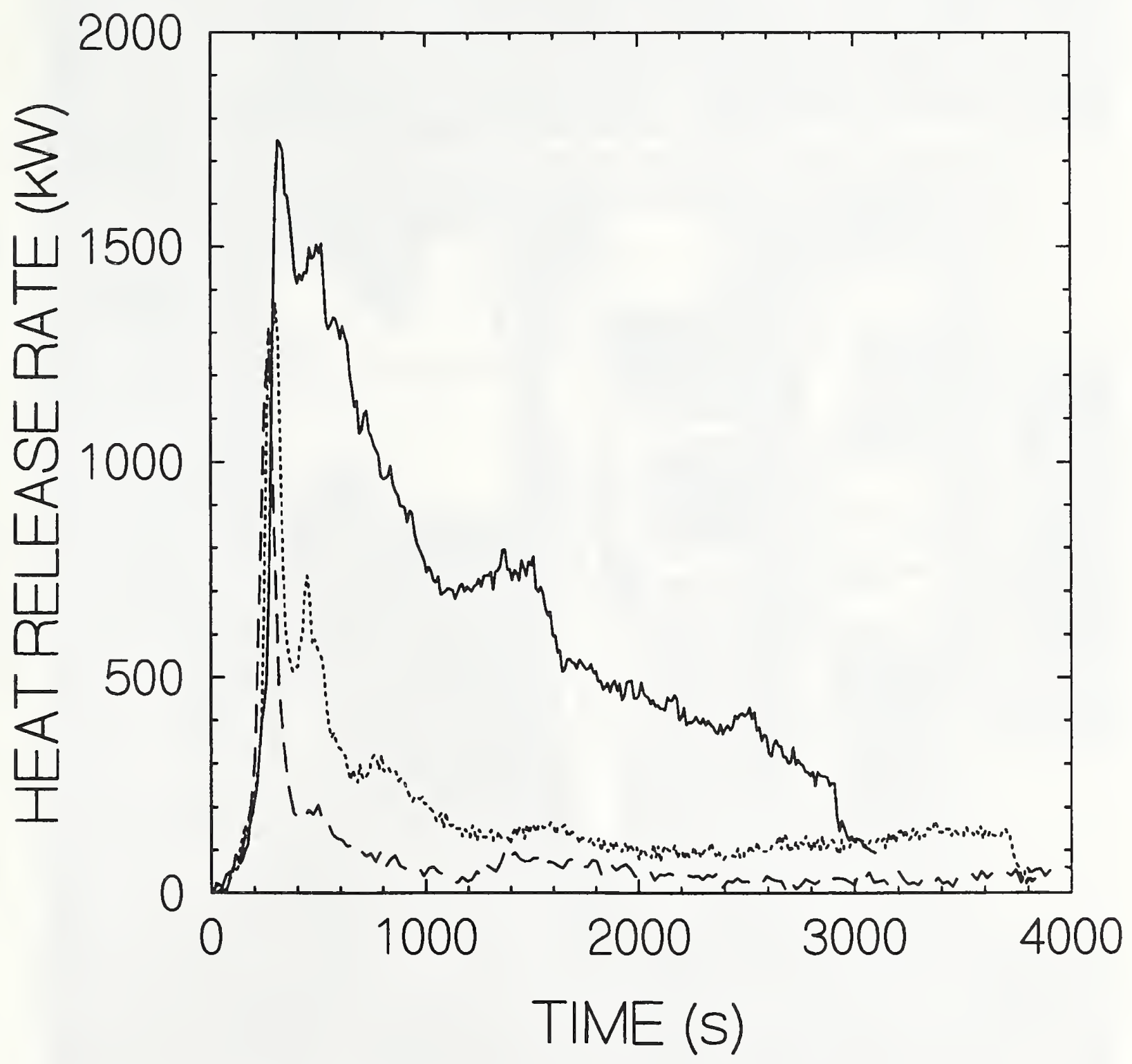

NON-SPRINKLERED

SPRINKLERED

- - - SPRINKLERED (REPLICATE)

Figure 11. Heat Release Rate Curves - Work Station I Fuel Package 


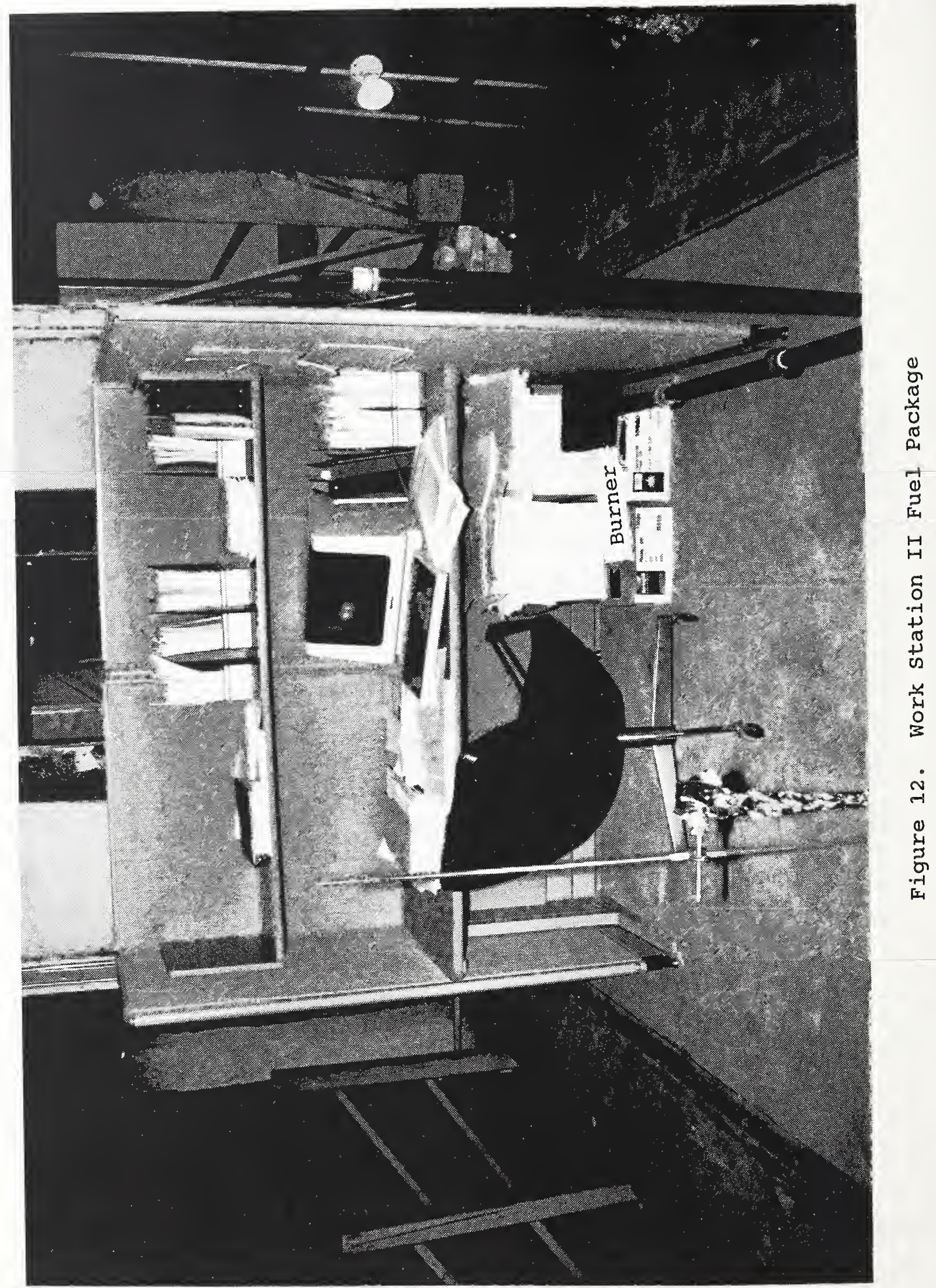




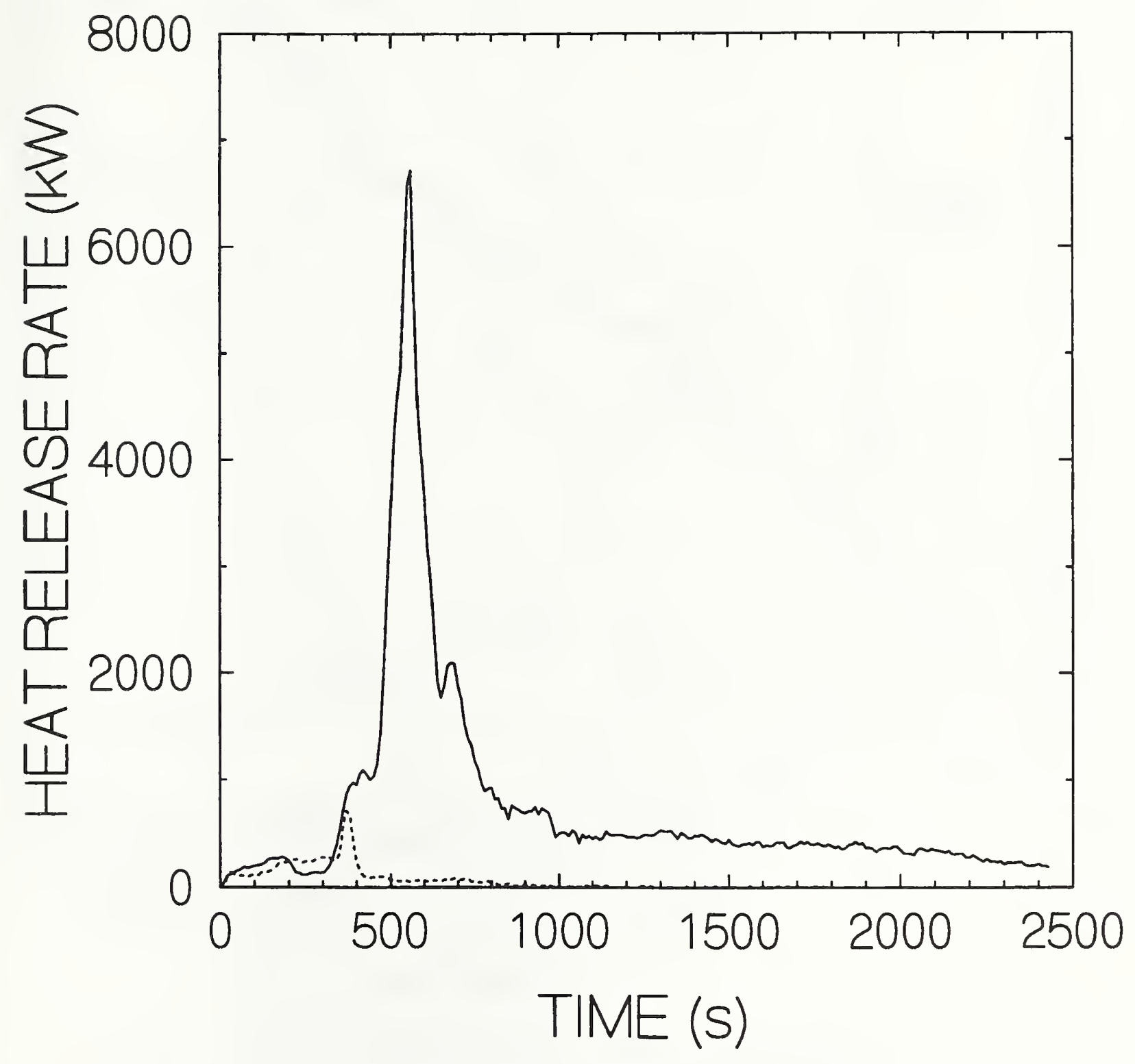

NON-SPRINKLERED

SPRINKLERED

Figure 13. Heat Release Rate Curves - Work Station II Fuel Package 


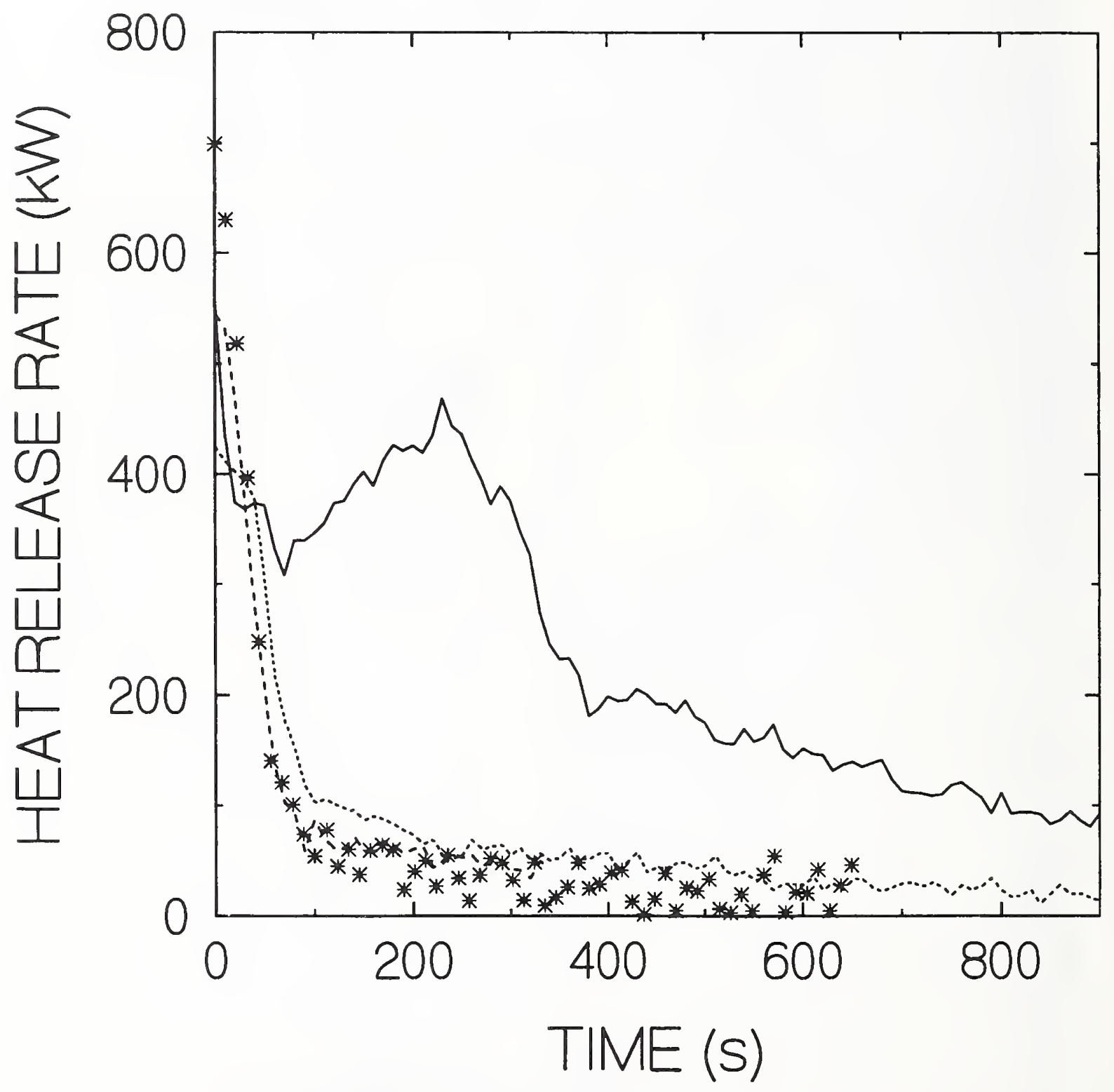

SECRETARIAL DESK FUEL PACKAGE

........ EXECUTIVE DESK FUEL PACKAGE

$\begin{array}{ll}* & \text { OFFICE II FUEL PACKAGE } \\ \text { PAPER CART FUEL PACKAGE }\end{array}$

Figure 14. Heat Release Rate Reduction Curves - Paper Recycling Cart, Office II, Executive Desk and Secretarial Desk Fuel Packages 


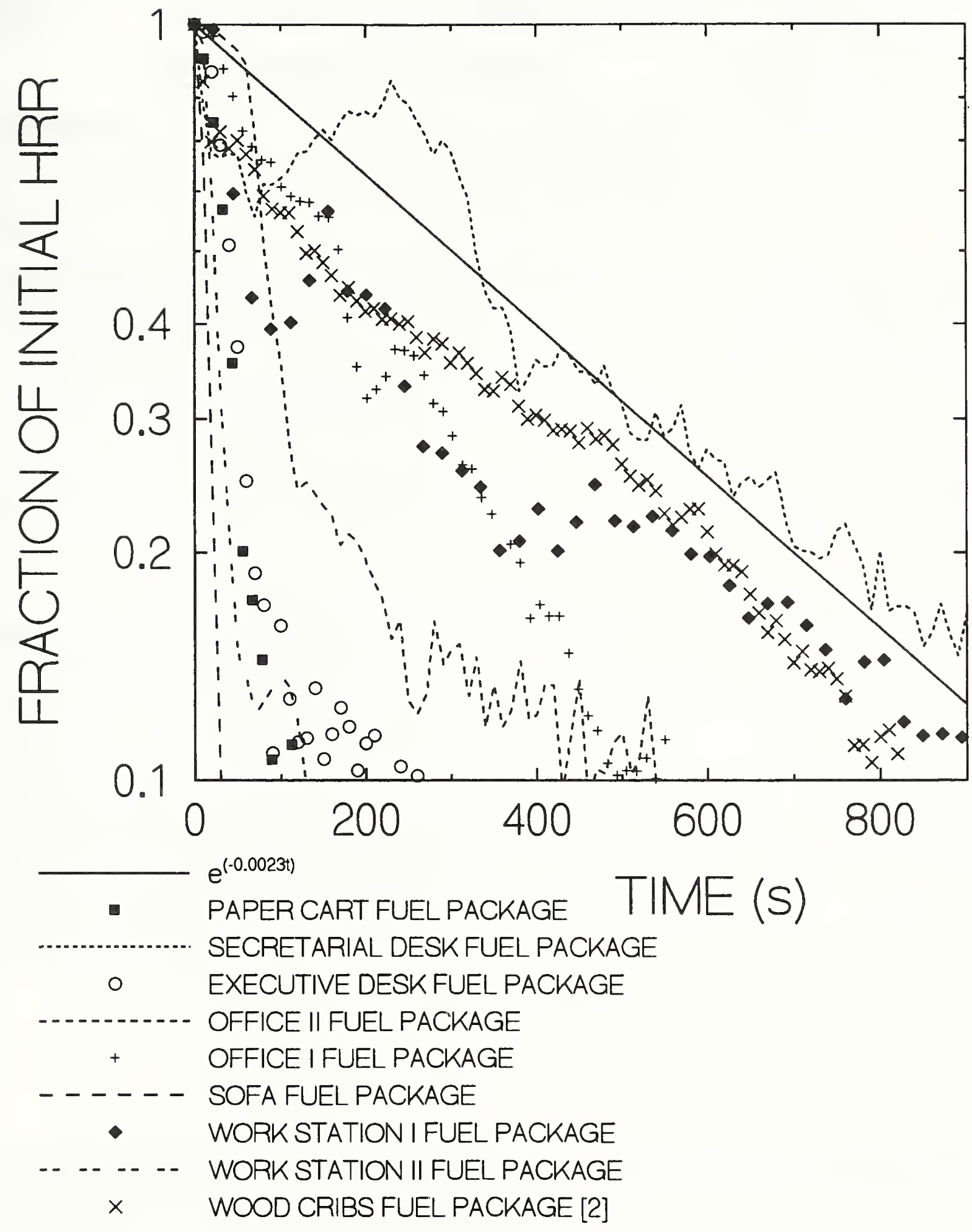

Figure 15. Envelope of Normalized Heat Release Rate Curves with HRR Reduction Curve 



\section{U.S. DEPARTMENT OF COMMERCE NATIONAL INSTITUTE OF STANDARDS AND TECHNOLOGY BIBLIOGRAPHIC DATA SHEET}

1. PUCLCATION OR REPORT MUMEER NISTIR 4833

2. PERFOALINO OACAMIZATION REPORT NUMBER

3. PULLCATION DATE MAY 1992

4. TITL NDD SUDTTIE

A Sprinkler Fire Suppression Algorithm for the GSA Engineering Fire Assessment System

5. AUTHON(\$)

Daniel Madrzykowski and Robert L. Vettor 1

6. PEAFOAMING OAQANIZATION (IF JOINT OR OTHEA THAN MIST, SEE INSTRUCTIONS)

U.s. DEPANTMENT OF COMMERCE

MATIONAL IASTITUTE OF STANDANDS AND TECHNOLOCY

oATHERSEURG, MD 20000

7. CONTAACT/ORANT MUMBEA

8. TYPE OF REPORT ND PERIOD COVERED

9. SPONSORIMG ORQNHIZATION MWRE NWD COMPLTE ADDAESS (STMET, CTY, STATE, ZIP)

General Services Administration

Public Butldings Service

Office of Real Property Management and Safety

Washington, DC 20405

10. SUPPLEMENTANY MOTES

11. AOSTRACT R ZOOWORD OR LESS FACTUAL SUMMARY OF MOST SIONIFICANT IMFORMATION. IF DOCUMENT INCLUDES A SIONIFICANT EIREOCRAPMY OR UTERATUAE SUAVEY, MENTION IT MENE)

A study was conducted to develop a sprinkler fire suppression algorithm for use with sprinkler activation time models. Large scale experiments were performed to determine the heat release rate (HRR) of selected office fuel packages with and without spr inklers operating. Eight different fuel packages were evaluated. The results from these experiments 0 if $55^{\prime}$ used to develop a time dependent HRR reduction factor. HRR Reduction Factor $=e^{-0.0023 t}$ where: $t=$ Time after sprinkler activation (s) The sprinkler fire suppression algorithm consists of multiplying the HRR reduction factor by the HRR at the time of sprinkler activation, $Q_{\text {act }}$, ylelding an expected opper bound to the HRR at a given time after sprinkler actfvatjon, $Q(t)$, for office furnishing fires that are not heavily shielded. $Q(t)=Q_{\text {act }} e^{-}$ This sprinkler fire suppression algorithm can be thought of as a "zeroth orger" $f i r e$ suppression model for "light hazard" occupancles with a sprinkler spray density of 0.07 mm/s $\left(0.1 \mathrm{gpm} / \mathrm{ft}^{2}\right)$ or greater.

12. KEY WOADS (6 TO 12 EMTAIES; ALPLAETICAL OADER; CAPTALZE OMLY PROPEN MWES; AND SEPARATE KEY WORDS OY SEMICOLONS) crlb fires; fire suppression; fire tests; fuel load; free burning fires; heat release rate; sprinkler 8

\section{AVALAEITTY}

FON OFFICLL DISTALUTION. DO MOT RELEASE TO MATHOMLL TECHACAL MFOAMATION SEAVTES (MTIS).

ORDER FROM SUPERIMTEMDEMT OF DOCUMENTS, U.S. GOVEAMLENT PNINTINO OFFICE, WASHINGTON, DC 20402

ORDER FROM MATIONAL TECHNICAL IMFORMATION SEAVCE (MTIS), SPAINOFIELD, VA 22161. 14. MUMBEA OF PAINTED PAQES

41

15. PराCe A03 

